(C) Podgorny K.A., Leonov A.V., 2020, Океанологические исследования, 2020, Том 48, № 2, C. $107-134$

UDK 574.5(261.24) + 574.5.001.57 + 551.463.8 DOI: 10.29006/1564-2291.JOR-2020.48(2).7

\title{
CALCULATION OF PARAMETER VALUES TO CHARACTERIZE THE CONSEQUENCES OF WORK ON THE DREDGING AND SUSPENDED MATTER DAMPING: ASSESSMENT BY MEANS OF THE SM-MODEL
}

\author{
Podgorny K.A. ${ }^{1}$, Leonov A.V. ${ }^{2}$ \\ ${ }^{1}$ Russian Federal Research Institute of Fisheries and Oceanography, Atlantic branch \\ 5, Dm. Donskoy str., Kaliningrad, 236000, Russia, \\ e-mail:kapborok@mail.ru \\ ${ }^{2}$ Shirshov Institute of Oceanology, Russian Academy of Sciences \\ 36, Nakhimovsky prospekt, Moscow, 117997, Russia, \\ e-mail:leonov@ocean.ru \\ Submitted 06.07.2020, accepted 28.08.2020
}

\begin{abstract}
The developed SM-model, describing the suspended matter concentrations in water environment, was used to assess the consequences of the works on dredging and dumping ground during the reconstruction and modernization of the water body area in the Pionersky Port (Kaliningrad region). The complex of recreated works includes 11 stages of the dredging works during which the various types of bottom sediments are extracted, some part of these sediments are transported outside the port water area and discharged into the marine underwater dump, while other their part are used for hydraulic engineering works in the port area. At the dredging and dumping the sediments, additional zones of water turbidity are formed (with a suspended matter concentration $>50 \mathrm{mg} / \mathrm{L}$ ), its deposition causes the formation of a layer of sediments on the bottom. For each work stages, the technological data on the currents in the port water area are used for mathematical modeling and calculations of the amounts of various types of sediments extracted from the bottom, their redistribution over the sea area, the concentration of suspended matter in sea water, and the indicators (areas and volumes) of the emerging turbidity zones water due as a result of the construction works. Calculated data may be used to compile a report "Assessment of influence on the water environment state" (or AIWES) in the frame of these works.
\end{abstract}

Keywords: natural factors (wind, sea currents, properties of bottom sediments); technological data on dredging and dumping of sediments; calculations of sediment losses, formation of suspended matter, parameters (areas and volumes) of areas of increased turbidity of water, accumulation of precipitated suspended matter layer at the bottom

The reliable operation of seaports requires maintaining and improving the existing infrastructure, carrying out work on the reconstruction and construction of new terminals and other engineering facilities capable of servicing large cruise liners and cargo-passenger ships. Such tasks are carried out with the implementation of a complex set of works on dredging, excavation and movement of significant amounts of bottom sediments both in the territory of seaports and outside them during their transport and discharges into underwater dump. Such works as dredging, dumping and movement of bottom sediments 
lead to significant disturbances in the state of the marine environment, the formation of zones of increased water turbidity, deterioration of the state and quality of the marine environment, which directly affects the state of aquatic biological resources and the conditions for their subsequent recovery.

Various approaches and methods are used to assess the environmental impact of hydrodynamic regimes of different spatial and temporal scales, as well as industrial dredging works on the marine aquatic environment. Simulation mathematical modeling is used as such a research method, and its application provides quantitative information when assessing the impact of factors such as dredging, placement of sediments removed during dredging at the bottom of water bodies, sediment dumping as well as when solving a number of other problems of environmental control and monitoring of the marine environment state. A simulation mathematical model of the distribution of suspended matter (SM-model), which is necessary for such studies of the possible ecological impact on the marine environment, was developed by the authors of this work and published (Podgorny, Leonov, 2017a). This SM-model and the corresponding computer program have been tested in a number of socially significant projects and have proven their effectiveness (Podgorny, 2003; Podgorny, Leonov, 2017b).

The purpose of this study is to characterize the capabilities of the mathematical SM-model on the example of the implementation of the project "Construction of sea port infrastructure in the seaport of Kaliningrad. International marine terminal for receiving cruise and cargo-passenger ships in the Pionersky Port, Kaliningrad region", as well as to show the use of information necessary for the application of the SM-model to quantitatively assess the consequences of dredging and construction work - in particular, the formation of temporary zones of additional water turbidity (AWT) in the seaport water area and a deposited SM-layer on the bottom.

\section{Description of work area and main technological data}

The examined object of research is the water area of the sea terminal in Pionersky Port (northern coast of the Sambian Peninsula). It is planned to create a new coastal infrastructure of the terminal on an area of $34220 \mathrm{~m}^{2}$ excluding the areas of hydraulic technical structures (GTS) - berths, coastal protection, safeguard structures. The scope of works for the formation of these territories includes 264,600 $\mathrm{m}^{3}$ of sediments (excluding its volume for the GTS constructions). It is estimated to use $\sim 961.7$ thousand $\mathrm{m}^{3}$ of sandy sediments for the whole construction works.

The area of dredging works is 30.61 ha. The estimated total volume of dredging (1252450 $\mathrm{m}^{3}$ of sediments) includes excavation: sands (from medium size to large) and gravel (IGE 3a) - $462960 \mathrm{~m}^{3}$; sand - from dusty to small (IGE 3b) - $58040 \mathrm{~m}^{3}$; heavy sandy soft-plastics loams (IGE $3 \mathrm{~g}$ ) - $29310 \mathrm{~m}^{3}$; sand of medium size (IGE 6a) $595990 \mathrm{~m}^{3}$; heavy hard clays (IGE 6g1) - $106150 \mathrm{~m}^{3}$. The work also includes excavation of the sediments in the protection zone (width $10 \mathrm{~m}$ ) along the berths - only $41110 \mathrm{~m}^{3}$ of sediments (from the total volume of the excavation): sands (from medium to large size) 
and gravel (IGE 3a) - $9620 \mathrm{~m}^{3}$; sand - from dusty to fine (IGE 3b) - $4250 \mathrm{~m}^{3}$; sand of medium size (IGE 6a) - $22370 \mathrm{~m}^{3}$; heavy hard clays (IGE 6g1) - $4870 \mathrm{~m}^{3}$.

There is a useful use of sediments extracted by dredging for construction purposes - in the works on the terminal area and construction of GTS. The most useful in construction are the sands of medium size recovered during dredging (IGE 3a and IGE 6a). The total volume of their excavation is $1058950 \mathrm{~m}^{3}$, except extracted from guard zone of berths $-1026960 \mathrm{~m}^{3}$. The development of sandy sediments follows from the line of the project profile of dredging towards the open sea (layers not more than $0.4 \mathrm{~m}$ thick). The extracted sediments will be transported in the form of a water-sediment mixture by pressure hydrotransport along the floating and shore slurry pipelines, and by washing up on the shore - without a cauldron by the pioneer-end scheme.

The specificity of the project is that it includes 11 different stages of work. Table 1 shows the technological data that determine the sequence and duration of work on dredging; volumes of sediments for the construction of the hydraulic technological system (or GTS) and its dumping in the marine underwater dump; the timing of each work stages; information on the dredgers used. The duration of the individual work stages varies within $0.4-74.5$ days, the stage 3 is a shortest stage; and the stage 8 is a longest one. At the indicated stages, the volume of the moved sediment varies accordingly from the smallest number $\left(2125 \mathrm{~m}^{3}\right)$ to the largest $\left(498730 \mathrm{~m}^{3}\right)$. The maximum area of bottom damage does not depend on the duration of the work stages, at the dredging it will vary within 0.05-29.06 ha, and at the sediment dumping it will be 100 hectares (Table 1).

The execution of each working stage was accompanied by the formation of AWT zones and the accumulation of SM-layer deposited at the bottom, which are quantitatively estimated using the developed SM-model. It was assumed that at a concentration of SM $>50 \mathrm{mg} / \mathrm{L}$, dredging and work on sediment dumping into an underwater dump lead to the death of planktonic organisms and thereby have a significant impact on the state of aquatic biological resources.

Table 1. Stages, duration, parameter values and dates of dredging operations in the water terminal area in Pionersky Port and ground discharge into the marine underwater dump. Type of dredgers used for ground dredging and dumping: 1. a single-dredge dredger; 2 . the dredger barge; 3 . self-hauling bilge pump "Glenford"; 4. clamshell dredge; 5. floating and coastal slurry pipelines; (* for the construction of GTS)

\begin{tabular}{|c|c|c|c|c|c|}
\hline Work stages & $\begin{array}{c}\text { Duration } \\
\text { of work, } \\
\text { days }\end{array}$ & $\begin{array}{c}\text { Area of } \\
\text { bottom } \\
\text { damage, } \\
\text { ha }\end{array}$ & $\begin{array}{c}\text { Volume } \\
\text { of drifted } \\
\text { ground, } \mathrm{m}^{3}\end{array}$ & $\begin{array}{l}\text { Type of dredgers, } \\
\text { used at ground } \\
\text { dredging and } \\
\text { discharge; } \\
\text { number of ground } \\
\text { discharges } \\
\text { [total (for } 1 \text { day)] }\end{array}$ & $\begin{array}{c}\text { Work } \\
\text { period, } \\
\text { month of year }\end{array}$ \\
\hline $\begin{array}{l}\text { 1. Dredging } \\
\text { Ground discharge }\end{array}$ & $\begin{array}{l}4.0 \\
4.0 \\
\end{array}$ & $\begin{array}{c}0.76 \\
100 \\
\end{array}$ & $\begin{array}{l}18931 \\
18931 \\
\end{array}$ & $\begin{array}{c}1 \\
2[48(12)]\end{array}$ & $\begin{array}{c}\text { January } \\
2017\end{array}$ \\
\hline $\begin{array}{l}\text { 2. Dredging } \\
\text { Ground discharge }\end{array}$ & $\begin{array}{l}6.1 \\
6.1\end{array}$ & $\begin{array}{c}0.76 \\
100\end{array}$ & $\begin{array}{l}21640 \\
21640\end{array}$ & $\begin{array}{c}1 \\
2[55(9)]\end{array}$ & $\begin{array}{c}\text { January } \\
2017\end{array}$ \\
\hline
\end{tabular}




\begin{tabular}{|c|c|c|c|c|c|}
\hline $\begin{array}{l}\text { 3. Dredging } \\
\text { Ground discharge }\end{array}$ & $\begin{array}{l}0.4 \\
0.4 \\
\end{array}$ & $\begin{array}{l}0.76 \\
100 \\
\end{array}$ & $\begin{array}{l}2125 \\
2135 \\
\end{array}$ & $\begin{array}{c}1 \\
2[6(6)] \\
\end{array}$ & $\begin{array}{c}\text { January } \\
2017 \\
\end{array}$ \\
\hline $\begin{array}{l}\text { 4. Dredging } \\
\text { Ground discharge }\end{array}$ & $\begin{array}{l}6.5 \\
6.5\end{array}$ & $\begin{array}{c}29.06 \\
100\end{array}$ & $\begin{array}{l}29310 \\
29310\end{array}$ & $\begin{array}{c}1 \\
2[74(12)]\end{array}$ & $\begin{array}{c}\text { January } \\
2017\end{array}$ \\
\hline $\begin{array}{l}\text { 5. Dredging } \\
\text { Ground discharge }\end{array}$ & $\begin{array}{l}7.4 \\
7.4\end{array}$ & $\begin{array}{c}29.06 \\
100\end{array}$ & $\begin{array}{l}34860 \\
34860\end{array}$ & $\begin{array}{c}1 \\
2[88(12)]\end{array}$ & $\begin{array}{c}\text { January } \\
2017\end{array}$ \\
\hline $\begin{array}{l}\text { 6. Dredging } \\
\text { Ground discharge* }\end{array}$ & $\begin{array}{l}69.5 \\
29.8\end{array}$ & $\begin{array}{c}29.06 \\
5.09\end{array}$ & $\begin{array}{l}462970 \\
198370\end{array}$ & $\begin{array}{l}3 \\
5\end{array}$ & $\begin{array}{c}\text { January-March } \\
2017\end{array}$ \\
\hline $\begin{array}{l}\text { 7. Dredging } \\
\text { Ground discharge }\end{array}$ & $\begin{array}{l}23.9 \\
23.9\end{array}$ & $\begin{array}{c}29.06 \\
100 \\
\end{array}$ & $\begin{array}{l}84510 \\
84510\end{array}$ & $\begin{array}{c}1 \\
2[212(9)]\end{array}$ & $\begin{array}{l}\text { April } \\
2017\end{array}$ \\
\hline $\begin{array}{l}\text { 8. Dredging } \\
\text { Ground discharge* }\end{array}$ & $\begin{array}{l}74.8 \\
74.8\end{array}$ & $\begin{array}{c}29.06 \\
5.09\end{array}$ & $\begin{array}{l}498730 \\
498730\end{array}$ & $\begin{array}{l}3 \\
5\end{array}$ & March-May 2017 \\
\hline $\begin{array}{l}\text { 9. Dredging } \\
\text { Ground discharge }\end{array}$ & $\begin{array}{l}5.8 \\
5.8\end{array}$ & $\begin{array}{c}29.06 \\
100\end{array}$ & $\begin{array}{l}63130 \\
63130 \\
\end{array}$ & $\begin{array}{c}3 \\
3[76(13)]\end{array}$ & $\begin{array}{c}\text { August } \\
2017\end{array}$ \\
\hline $\begin{array}{l}\text { 10. Dredging } \\
\text { Ground discharge }\end{array}$ & $\begin{array}{l}0.9 \\
0.9 \\
\end{array}$ & $\begin{array}{l}0.05 \\
100 \\
\end{array}$ & $\begin{array}{l}4250 \\
4250 \\
\end{array}$ & $\begin{array}{c}4 \\
2[11(11)] \\
\end{array}$ & $\begin{array}{c}\text { August } \\
2017 \\
\end{array}$ \\
\hline $\begin{array}{l}\text { 11. Dredging } \\
\text { Ground discharge }\end{array}$ & $\begin{array}{l}6.8 \\
6.8\end{array}$ & $\begin{array}{c}0.74 \\
100\end{array}$ & $\begin{array}{l}31990 \\
31990\end{array}$ & $\begin{array}{c}4 \\
2[80(12)]\end{array}$ & $\begin{array}{c}\text { August } \\
2017\end{array}$ \\
\hline
\end{tabular}

\section{Data for the characterization of the natural marine water environment}

Within the framework of this study, the initial data (meteorological, oceanological, granulometric composition of soils, etc.) necessary for calculations on the SM-model are briefly considered, since environmental factors have a direct impact on the processes of formation, distribution and propagation of the SM in the marine environment. The initial data (meteorological, oceanological, granulometric composition of soils, etc.) necessary for calculations on the SM-model are briefly considered, since environmental factors have a direct impact on the processes of formation, distribution and circulation of the SM in the marine environment. Such natural factors include wind, sea currents, temperature $(\mathrm{Tw})$, salinity ( $\mathrm{Sw}$ ) of sea water, and the nature of bottom sediments (BS).

Wind. The wind regime for this area of the Baltic Sea was characterized according to the data at the coastal station, which are discussed in (Podgorny, Leonov, 2017b: Fig. 1-4, tab. 1):

- repeatability and wind speed for eight points above the sea surface in the area of planned works (Kaliningrad region);

- wind speed and direction at a height of $10 \mathrm{~m}$ above sea level: according to the recalculated (according to formula (1), Appendix) observation data at the OIRFP D-6 station at an altitude of $27 \mathrm{~m}$ ).

For 2004-2009, the average values of wind speeds and directions and their rootmean-square deviations were estimated for each month for January-May and August over the work area; mean annual wind speed varies from 5.8 to $8.2 \mathrm{~m} / \mathrm{s}$ (average $7.2 \mathrm{~m} / \mathrm{s}$ ), wind direction - from 148 to $202^{\circ}$ (average $188^{\circ}$ ) with standard deviations of $\pm 1.4 \mathrm{~m} / \mathrm{s}$ and $\pm 77^{\circ}$. The prevailing winds of the southwestern, southern and southeastern 
directions, their speed at a height of $10 \mathrm{~m}$ above the water surface is higher than the wind speed over land by $\sim 1.5-3.0 \mathrm{~m} / \mathrm{s}$. In summer, the frequency of western winds increases (up to 45-60\%), while that of eastern and southeastern winds decreases (Oil and the environment..., 2012). In autumn, the frequency of westerly winds is $30-40 \%$, and that of southeastern and southern winds is $\sim 30 \%$; in October, their frequency increases, and the frequency of southwestern winds decreases to $15-30 \%$.

Currents. Wind influence on the sea surface, seasonal variability of hydro- and meteorological conditions, and inertial effects of Earth's rotation are the main factors influencing on the speed, direction and vertical structure of the currents in the work area (Oil and the environment of the Kaliningrad region, 2012). The bottom morphometry and its changes during dredging influence on the currents in the terminal water area. According to available observations, the current velocity in the dumping area of sediments in the marine underwater dump does not exceed $20 \mathrm{~cm} / \mathrm{sec}$. Its average value at the sea surface is $\sim 10-12 \mathrm{~cm} / \mathrm{sec}$, and in the near-bottom water layer it is $6-10 \mathrm{~cm} / \mathrm{sec}$. In the summer, a layered structure of currents can be established due to the development of the thermocline with the space-time dynamics of their inertial oscillations in the work area at the sediment dumping in the marine underwater dump (Oil and the environment of the Kaliningrad region, 2012). In autumn and winter, currents are usually uniform on the depth and depend on the variability of the wind. Therefore, in the works on mathematical modeling, it is possible to apply current model equations constructed on the basis of a theory for the shallow water system.

Temperature $T_{W}$ and salinity $S_{W}$ of sea water. During 2004-2009 on the selected sections of the Baltic Sea, 20 surveys of hydrological observations of $T_{W}$ and $S_{W}$ were performed (Oil and the environment of the Kaliningrad region, 2012). The average summer (in July) $T_{W}$ on the sea surface was $18.2^{\circ} \mathrm{C}$, and the average annual $-10.4^{\circ} \mathrm{C}$. In summer, $S_{W}$ is minimal (7.05\%) with an average annual value of $7.17 \%$.

Characteristics of the sediments in the work area. Table 2 shows the granulometric composition of types of sediments being transported to:

- stages 1-3 - up to the mark of -7.8 m (profiles 2-2-4-4), respectively, dusty sand (IGE 3b), heavy hard clay (IGE 6g1) and medium-sized sand (IGE 6a);

- stages 4-9 - up to the mark of $-10.9 \mathrm{~m}$ (profiles 5-5-22-22) - heavy sandy softplaster loam (IGE 3g), dusty sand (IGE 3b), medium-sized sand (IGE 6a), heavy hard clay IGE 6g1), medium-sized sand (IGE 6a), and medium-sized sand - second group (IGE 3a);

- stage 10 - to the mark of -7.8 (10-meter zone at the berths) - dusty sand (IGE 3b);

- stage 11 - to the mark of $-10.9 \mathrm{~m}$ (10-meter zone at the berths) - sand of medium size (IGE 6a) + loam of heavy sandy soft-plaited (IGE 3g). 
Podgorny K.A., Leonov A.V.

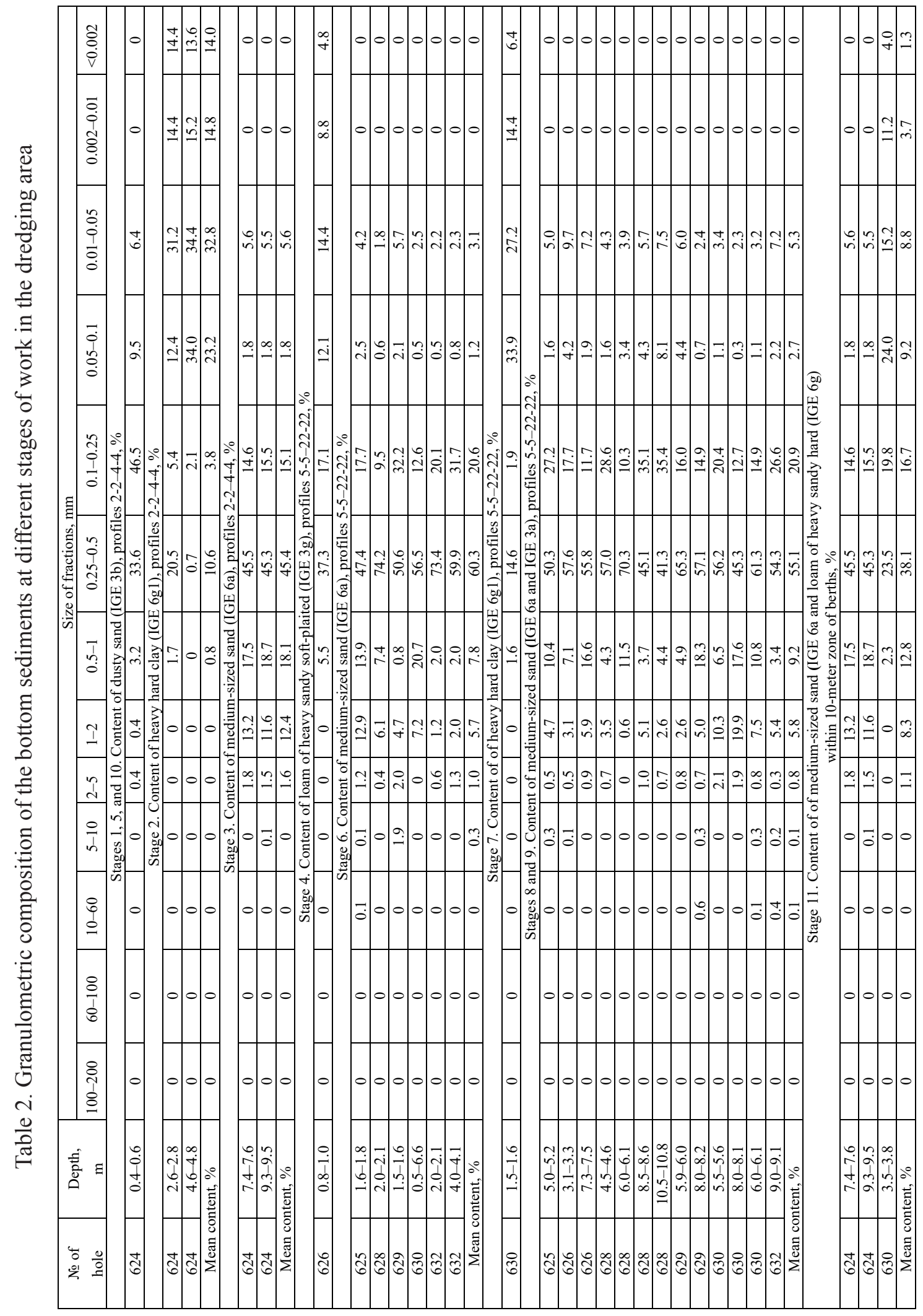


In stages 6 and 8, the sediments are used for the construction of GTS on the port territory.

Next, we will estimate the parameter values by the equations (Appendix), which will allow us to perform calculations on the SM-model and determine the consequences of dredging and dumping of sediments and, in particular, on the state of bottom surface and on the SM concentrations in the water environment. The required calculations for each stage of work on individual parameters are the same. To illustrate their sequence, as an example, we use only the initial data for the first stage of the work, and for the remaining work stages, we present the final results of the calculations in the corresponding tables and on the graphs.

First of all, according to Table 2, we calculate of the $P_{n}$ fraction values of SM particles $\leq 0.1 \mathrm{~mm}$ in size, and their sums $P$ for each work stages (Table 3 ).

Table 3. The calculated values of $P_{n}$ fractions of SM particles with size $\leq 0.1 \mathrm{~mm}$ and their sum values $P$ (in quotas from 1 )

\begin{tabular}{|c|c|c|c|c|c|c|}
\hline \multirow{2}{*}{ № of stage, type of ground } & \multicolumn{5}{|c|}{ Size of $P_{n}$ fractions, $\mathrm{mm}$} & \multirow{2}{*}{$P$} \\
\hline & $0.1-0.25$ & $0.05-0.1$ & $0.01-0.05$ & $0.002-0.01$ & $<0.002$ & \\
\hline \multicolumn{7}{|c|}{ Dredging of area to the mark $-7.8 \mathrm{~m}$, profiles $2-2-4-4$} \\
\hline 1. dusty sand (IGE 3b) & 0.233 & 0.095 & 0.064 & 0.000 & 0.000 & 0.392 \\
\hline 2. heavy hard clay (IGE $6 \mathrm{~g} 1$ ) & 0.019 & 0.232 & 0.328 & 0.148 & 0.140 & 0.867 \\
\hline 3. mean-sized sand (IGE 6a) & 0.076 & 0.018 & 0.056 & 0.000 & 0.000 & 0.150 \\
\hline \multicolumn{7}{|c|}{ Dredging of area to the mark $-10.9 \mathrm{~m}$, profiles $5-5-22-22$} \\
\hline 4. loam heavy (IGE 3g) & 0.086 & 0.121 & 0.144 & 0.088 & 0.048 & 0.487 \\
\hline 5. dusty sand (IGE 3b) & 0.233 & 0.095 & 0.064 & 0.000 & 0.000 & 0.392 \\
\hline 6. mean-sized sand (IGE 6a) & 0.103 & 0.012 & 0.031 & 0.000 & 0.000 & 0.146 \\
\hline 7. heavy clay (IGE 6g1) & 0.010 & 0.339 & 0.272 & 0.144 & 0.064 & 0.829 \\
\hline 8. mean-sized sand (IGE 6a) & 0.105 & 0.027 & 0.053 & 0.000 & 0.000 & 0.185 \\
\hline $\begin{array}{l}\text { 9. mean-sized sand (IGE 6a) - } \\
\text { second group (IGE 3a) }\end{array}$ & 0.010 & 0.339 & 0.272 & 0.144 & 0.064 & 0.829 \\
\hline \multicolumn{7}{|c|}{ Dredging of area to the mark $-7.8 \mathrm{~m}$, zone of 10 -meters around berths } \\
\hline 10. dusty sand (IGE 3b) & 0.233 & 0.095 & 0.064 & 0.000 & 0.000 & 0.392 \\
\hline \multicolumn{7}{|c|}{ Dredging of area to the mark $-10.9 \mathrm{~m}$, zone of 10 -meters around berths } \\
\hline $\begin{array}{l}\text { 11. mean-sized sand + loam } \\
(\text { IGE 6a + IGE 3g) }\end{array}$ & 0.084 & 0.092 & 0.088 & 0.037 & 0.013 & 0.314 \\
\hline
\end{tabular}

Further, data on the granulometric sediments composition make it possible to determine the ranges of the change in the average scales of the roughness protrusions of the bottom $Z_{0}$ (Stanev et al., 2009) $\left(Z_{0}=D_{50} / 12\right.$ where $D_{50}$ is the weighted average particle size) and by equation (2) (Appendix) - average sedimentation rate of SM particles, $W_{S}$, at different stages of dredging in the work area. According to Table 2, for stage 1 of dredging (up to $-7.8 \mathrm{~m}$, profiles 2-2-4-4; dusty silt, IGE $3 \mathrm{~b}$ ), we calculate the values of $D_{50}$ from the sample of fractions (separately at the upper and lower boundaries of the size intervals): 
- on the upper border $-D_{50}=5 \times 0.004+2 \times 0.004+1 \times 0.032+0.5 \times 0.336+$ $0.25 \times 0.465+0.1 \times 0.095+0.05 \times 0.064=0.357(\mathrm{~mm})$;

- on the lower border $-D_{50}=2 \times 0.004+1 \times 0.004+0.5 \times 0.032+0.25 \times 0.336+$ $0.1 \times 0.465+0.05 \times 0.095+0.01 \times 0.064=0.164(\mathrm{~mm})$.

Thus, for stage 1 on the upper boundary of the size intervals, the average scale $Z_{0}$ of the height of the roughness protrusions is $Z_{0}=D_{50} / 12=0.357 / 12=0.0298 \mathrm{~mm}$ (or $2.98 \times 10^{-5} \mathrm{~m}$ ), and for the lower $Z_{0}=D_{50} / 12=0.164 / 12=0.0137 \mathrm{~mm}\left(\right.$ or $\left.1.37 \times 10^{-5} \mathrm{~m}\right)$. Next, the average scale $Z_{0}$ of the height of the roughness protrusions of the bottom is taken into account for step 1 due to dust particles (IGE 3b) equal to $(0.0298+0.0137) / 2=$ $0.0218 \mathrm{~mm}$ (or $2.18 \times 10^{-5} \mathrm{~m}$ ).

Similarly, we calculate the values of $D_{50}$ and $Z_{0}$ for the work stages of 2-11 and add these calculated indices in Table 4 . The highest values of $Z_{0}$ were obtained for the work stage $3(0.0481 \mathrm{~mm})$, they were increased for the work stages $8-9(0.0395 \mathrm{~mm})$, $6(0.0388 \mathrm{~mm}), 11(0.0368 \mathrm{~mm})$, and small values were obtained for the stages $2(0.0068 \mathrm{~mm})$ and $7(0.0087 \mathrm{~mm})$.

Table 4. Values of individual coefficients used to calculate parameters determining the impact of dredging and dumping operations on the SM redistribution in the work water area (the Pionersky Port)

\begin{tabular}{|c|c|c|c|c|c|c|c|c|c|c|}
\hline \multirow{2}{*}{$\begin{array}{c}\text { Stage } \\
\text { of } \\
\text { work }\end{array}$} & \multicolumn{2}{|c|}{$\begin{array}{l}\text { Calculated values of } D_{0} \text {, } \\
\text { mm, estimated for }\end{array}$} & \multirow{2}{*}{$\begin{array}{c}\text { Mean } \\
\text { scale of } \\
Z_{0}, \mathrm{~mm}\end{array}$} & \multirow{2}{*}{$\begin{array}{l}W_{S} \\
\mathrm{~m} / \mathrm{sec}\end{array}$} & \multirow{2}{*}{$\begin{array}{l}\gamma \\
\mathrm{t} / \mathrm{m}^{3}\end{array}$} & \multirow{2}{*}{$\underset{\mathrm{t} / \mathrm{m}^{3}}{\gamma_{s}}$} & \multirow{2}{*}{$\begin{array}{c}q \\
\mathrm{~g} / \mathrm{sec}\end{array}$} & \multirow{2}{*}{\begin{tabular}{|c|} 
Taken mean \\
depth of \\
dredging \\
region, \\
m \\
\end{tabular}} & \multirow{2}{*}{\begin{tabular}{|c|} 
Mass of SM, \\
entering \\
into water at \\
dredging, \\
$\mathrm{t}$ \\
\end{tabular}} & \multirow{2}{*}{$\begin{array}{c}\text { Mean vertical } \\
\text { concentration } \\
\text { of SM entering } \\
\text { into water in one } \\
\text { second, } \mathrm{mg} / \mathrm{L}\end{array}$} \\
\hline & $\begin{array}{l}\text { Upper size } \\
\text { interval of } \\
\text { boundary }\end{array}$ & $\begin{array}{c}\text { Lower size } \\
\text { interval of } \\
\text { boundary }\end{array}$ & & & & & & & & \\
\hline 1 & 0.357 & 0.164 & 0.0218 & 0.00351 & 1.92 & 2.69 & 4716.67 & 5 & 1630.08 & 943.33 \\
\hline 2 & 0.112 & 0.050 & 0.0068 & 0.00052 & 1.94 & 2.72 & 7937.43 & 7 & 4183.34 & 1133.92 \\
\hline 3 & 0.778 & 0.377 & 0.0481 & 0.00288 & 1.99 & 2.69 & 2180.02 & 7 & 75.34 & 311.43 \\
\hline 4 & 0.305 & 0.146 & 0.0188 & 0.00131 & 1.98 & 2.74 & 5883.36 & 10 & 3304.09 & 588.34 \\
\hline 5 & 0.357 & 0.164 & 0.0218 & 0.00351 & 1.92 & 2.69 & 4694.66 & 10 & 3001.58 & 469.47 \\
\hline 6 & 0.628 & 0.303 & 0.0388 & 0.00387 & 1.93 & - & 0 & - & 0 & 0 \\
\hline 7 & 0.143 & 0.066 & 0.0087 & 0.00067 & 1.94 & 2.72 & 7564.89 & 10 & 15621.20 & 756.49 \\
\hline 8 & 0.651 & 0.296 & 0.0395 & 0.00323 & 1.99 & - & 0 & - & 0 & 0 \\
\hline 9 & 0.651 & 0.296 & 0.0395 & 0.00087 & 1.99 & - & 0 & - & 0 & 0 \\
\hline 10 & 0.357 & 0.164 & 0.0218 & 0.00450 & 1.92 & 2.69 & 4706.14 & 7 & 365.95 & 672.31 \\
\hline 11 & 0.595 & 0.287 & 0.0368 & 0.00239 & 1.97 & 2.71 & 3942.43 & 10 & 2316.26 & 394.24 \\
\hline
\end{tabular}

The average values of the roughness protrusions scale of the bottom for all values for each stage of work are:

$$
\begin{gathered}
Z_{0}=(2.18+0.68+4.81+1.88+2.18+3.88+0.87+3.95+3.95+2.18+ \\
+3.68) \times 10^{-5} / 11=2.75 \times 10^{-5} \mathrm{~m} .
\end{gathered}
$$

The approximate average rate of SM sedimentation is estimated by the method proposed in (Guidelines for calculating..., 2003), and the effective sedimentation rate of $\mathrm{SM}, W_{s}(\mathrm{sm} / \mathrm{sec})$, is calculated from equation (2) (Appendix) for each work stage. The calculation of the hydraulic size of individual fractions of particles was carried out for 
$T_{W}=5$ and $10^{\circ} \mathrm{C}$ (for January-April) and $15^{\circ} \mathrm{C}$ (May, August). For the work stage of 1 , the value $W_{S}$ is calculated according to equation (2) (Appendix), taking into account the data of Table 3 for dusty sand:

$W_{s}=\frac{0.530 \times 0.233+0.1426 \times 0.095+0.00593 \times 0.064+0.000414 \times 0.000+0.000059 \times 0.000}{0.392}=0.351$

here the coefficients $0.530,0.1426,0.00593,0.000414$, and 0.000059 determine the hydraulic size of the $\mathrm{SM}$ at $5^{\circ} \mathrm{C}$, respectively, with particle diameters of $0.1,0.05,0.01$, 0.002 and $0.0001 \mathrm{~mm}$; (at $10^{\circ} \mathrm{C}$, the values of these coefficients will be $0.604,0.164$, $0.00689,0.000482$ and 0.000069 , and at $15^{\circ} \mathrm{C}-0.679,0.1864,0.00784,0.000552$ and 0.000079 respectively for particles with the sizes $0.1,0.05,0.01,0.002$ and $0.0001 \mathrm{~mm}$ ). For the work stages of $9-11$, the values of the coefficients at $15^{\circ} \mathrm{C}$ are taken into account in the calculations of $W_{S}$. The calculated values of $W_{S}$ for all stages of work are given in Table 4: the highest values of $W_{S}(0.0045 \mathrm{~m} / \mathrm{sec})$ were obtained for the work stage of 10 , the elevated values $(0.00323-0.00381 \mathrm{~m} / \mathrm{sec})$ for stages of $8,1,5$, and 6 , and lower values $(0.00052-0.00087 \mathrm{~m} / \mathrm{sec})$ for stages of 2,7 , and 9 .

Next, we turn to the calculation of the rate of transition of the sediments to the suspended state $q$ in the course of dredging (Guidelines for calculating..., 2003) according to equation (3) (Appendix). For all stages of the work, two parameters of equation (3) the value of the coefficient of sediment transition into a suspended state at the equipment is operating, in quotas of $1(k=0.15)$, and the volume weight of water $\left(\gamma_{W}=1 \mathrm{t} / \mathrm{m}^{3}\right)$, are assumed to be the same. The values of the productivity of the technical means on the sediment $Q$ are calculated for each work stage taking into account their duration and the volumes of the moved sediments (Table 1). For example, for stage 1, the work duration is 4 days, and the volume of moving sediments is $18931 \mathrm{~m}^{3}$, hence the value of $Q=$ $18931 /(4 \times 24)=197.2 \mathrm{~m}^{3} / \mathrm{h}$. For each of the work stage, the values of the parameter $P$ are taken from Table 3, and the parameters $\gamma$ and $\gamma_{s}$ - from Table 4. For the work stage of 1 , the values of the parameters $\left(P, \gamma\right.$ and $\left.\gamma_{S}\right)$ are $P=0.392 \mathrm{~mm}, \gamma=1.92$ and $\gamma_{S}=2.69 \mathrm{t} / \mathrm{m}^{3}$. Then the value of the speed $q$ calculated for stage 1 will be

$$
q=\left(0.392 \times 0.15 \times 197.20 \times 2.69 \times \frac{1.92-1.0}{2.69-1.0}\right) / 3600=0.00471667 \mathrm{t} / \mathrm{sec}
$$

(or $4716.67 \mathrm{~g} \mathrm{SM} / \mathrm{sec}$ ), here 3600 is a unit of time, sec.

At the stages 6, 8, and 9 of the dredging, the self-hauling sludge dredger "Glänford" is used. It is working without loss of sediment $(k=0.0)$, and therefore AWT zones do not formed and $q=0.0$. The calculated values of $q$ for all work stages are presented in Table 4 .

Then an example is shown for the stage 1: it illustrates calculations of SM mass input and the mean vertical SM concentrations entering into water environment every second during the dredging activity. Time for the work stage of 1 was 4 days (or 96 hours), the bottom damage area was estimated $7600 \mathrm{~m}^{2}$ (or $0.76 \mathrm{ha}$ ) (Ta- 
ble 1), and the SM input into the water environment will be $4716.67 \times 3600 \times 96=$ $1630081152 \mathrm{~g}($ or $\approx 1630.08 \mathrm{t} \mathrm{SM})$. For average depth of $5 \mathrm{~m}$ (Table 4$)$ at the dredging on the work stage of 1 , the average vertical speed of SM entering into water for every second will be $4716.67 \mathrm{~g} /\left[\left(1 \mathrm{~m}^{2} \times 5 \mathrm{~m}\right.\right.$ ) sec $]=943.33 \mathrm{~g} \mathrm{SM} / \mathrm{m}^{3}$ (or $943.33 \mathrm{mg} \mathrm{SM} /(\mathrm{L} \times \mathrm{sec}$ ).

The SM mass enters into the water for every second at a certain speed at the discharge point. The calculation of the SM propagation zone is performed on the model taking into account values of flows, deposition, agitation, and other factors. Based on this, the area with a concentration of the $\mathrm{SM}>50 \mathrm{mg} / 1$, and the average SM concentration in it, and other characteristics are already calculated.

\section{Parameters of the grid region for the calculation of currents and the SM distribution in the water area}

The grid field (Fig. 1) includes the total number of nodes $79 \times 27$ (79 - along the horizontal axis OX and 27 - along the vertical axis OY). The selected step $h_{x}$ and $h_{y}$ with respect to the spatial coordinates $x$ and $y$ is a constant $(19 \mathrm{~m})$ with the area of one cell $\left(19 \times 19=361 \mathrm{~m}^{2}\right)$. The dimensions of grid area $78 \times 19 \mathrm{~m}=1482 \mathrm{~m}$ (along the OX axis) and $26 \times 19 \mathrm{~m}=494 \mathrm{~m}$ (along the $\mathrm{OY}$ axis), and the total area of the entire design area is $78 \times 26 \times 361=732,108 \mathrm{~m}^{2}(\sim 73.2 \mathrm{ha})$. The grid for calculations is created at the stage of data preparation for calculations on the SM-model using a real depth map and the designated configuration of the work area. Thus, the steps on the grid along the OX and OY axes are analogous to real meters. Since in the Surfer package the configuration of the coordinates of the computational domain is identified precisely by the numbers of the nodes, then Fig. 1 shows the numbers of grid nodes along the axes OX and OY.

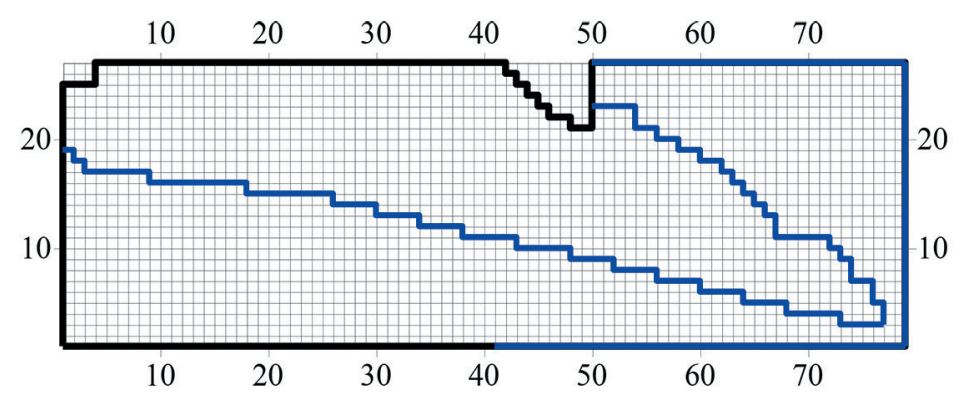

Fig. 1. Grid region for numerical integration of the system of Saint-Venant equations in the plane, and also systems of evolution equations of advection and turbulent diffusion in the calculation of the SM transport in the dredging work area (terminal of Pionersky Port). Here and in Fig. 2-4, the vertical axis OY and the horizontal axis OX include 27 and 79 grid nodes (the spatial step along the grid $h_{x}$ and $h_{y}$ is constant and equal to $19 \mathrm{~m}$; the total length of the OY axis $=494 \mathrm{~m}$, OX axis $=1482 \mathrm{~m}$ ).

Part of the boundary of the grid area is closed (solid), and the other part is open (sea) (in Fig. 1 they are shown respectively with black and blue lines on the axes OX and OY; broken blue lines inside the area is the area of dredging). Observations of the current 
velocities and water levels on open boundaries are absent, and during calculations the values of the free surface level are taken as zero. The uncertainty of the given boundary conditions in the calculation of the current field will not lead to significant distortions in the design velocities and current directions since the dimensions of the calculated region are large in comparison with the dimensions of the dredging area.

Maximum depth $H_{\max }=15.3 \mathrm{~m}$ within the grid field for the dredging area.

The value of the time step depends on the steps on the spatial grid coordinates. According to the CFL-criterion of the calculation stability (equation 4 in Appendix), the time step $\tau$ should be less than

$$
\frac{19}{\sqrt{9,81 \times 15,3}}=1,5 \mathrm{sec}
$$

For the convenience of calculations, we take the time step $\tau=1 \mathrm{sec}$ for the numerical integration of the systems of evolution equations of advection and turbulent diffusion in the calculation of the SM transport by currents in the region of dredging.

The horizontal turbulent exchange coefficient $\left(A_{\eta}\right)_{n}$ for size fractions $n$ is estimated from equation (5) (Appendix).

The processes of the SM sedimentation and stirring up of bottom sediments will develop only at the values of the shear stress at the bottom of the water body $\tau_{\text {bottom }}<\tau_{C_{n}}^{\text {crit_sed }}$ (determines the onset of SM sedimentation) or $>\tau_{C_{n}}^{\text {crit resusp }}$ (determines the beginning of the stirring up of the bottom sediments). Critical values $\tau_{C_{n}}^{\text {crit_sed }}$ vary within the range $\left(0-0.18 \mathrm{~N} / \mathrm{m}^{2}\right)$, and $\tau_{C_{n}}^{\text {crit resusp }}-$ in $\left(0.009-0.25 \mathrm{~N} / \mathrm{m}^{2}\right)$ [Chao et al., 2008; Hamilton, Mitchell, 1996; Lou et al., 2000; Mehta, Partheniades, 1975; Ziegler, Nisbet, 1995], and they are selected at the calibration of models used for the study of sediment transport in lakes, coastal marine zones and bays. The value $\tau_{\text {bottom }}^{\text {curr }}$ is calculated by the equation (7) (Appendix), and it is basic at the calculating $\tau_{\text {bottom }}$.

For calculations, we use the previously calculated values of the parameters $\left(Z_{0}=\right.$ $2.75 \times 10^{-5} \mathrm{~m}, Z_{W}=8.5 \mathrm{~m}$, water density $\gamma_{W}=1 \mathrm{t} / \mathrm{m}^{3}$ or $1000 \mathrm{~kg} / \mathrm{m}^{3}$, vertical average flow velocity $U^{\text {curr }}=0.1 \mathrm{~m} / \mathrm{sec}$ ). From the beginning, we use the equation (8) (Appendix) to calculate the value of the coefficient $C_{D}=0.00118062$, and then by the equation (7) the value of

$$
\tau_{\text {bottom }}^{\text {curr }}=\rho_{w} \times C_{D} \times\left(U^{\text {curr }}\right)^{2}=10^{3} \times 0.00118062 \times(0,1)^{2} \approx 0.012 \mathrm{~N} / \mathrm{m}^{2} .
$$

Further, as a first approximation, we assume that $\tau_{C_{n}}^{\text {crit_sed }}=0.01 \mathrm{~N} / \mathrm{m}^{2}$, and $\tau_{C_{n}}^{\text {crit_resusp }}=0.02 \mathrm{~N} / \mathrm{m}^{2}$.

\section{Spatial structure of flow fields: estimation by results of mathematical modeling}

The structure of flow fields in the dredging area is rather complicated because of the spatial variability of the morphometry of the computational region and the wind direction. Calculated flow fields for different wind directions (in eight rhumbes) and mean annual velocity of $6 \mathrm{~m} / \mathrm{sec}$ are shown in Fig. 2. 

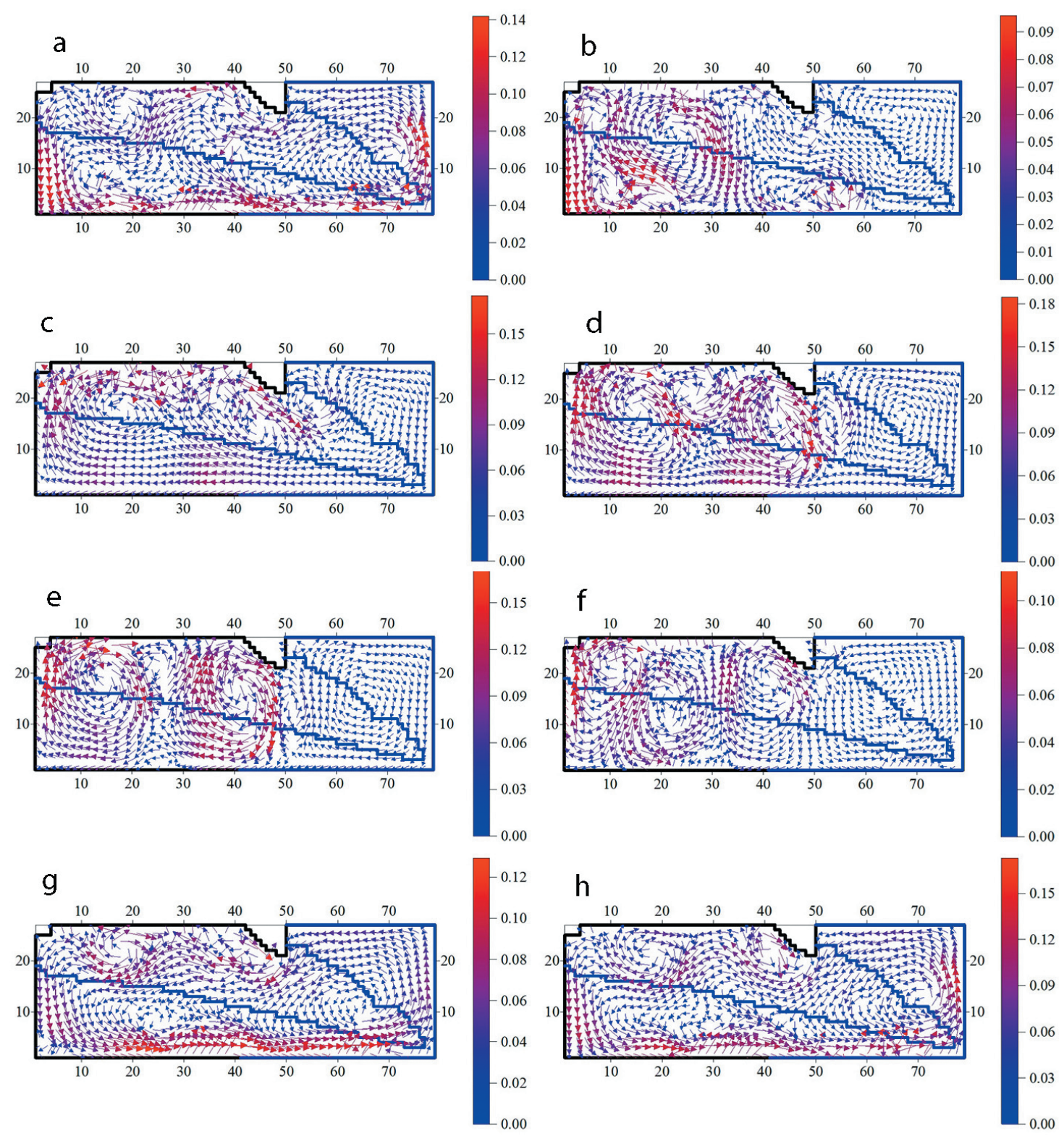

Fig. 2. Examples of flow fields $(\mathrm{m} / \mathrm{sec})$ calculated on the mathematical model in the area of dredging (terminal in Pionersky Port) at the wind speed of $6 \mathrm{~m} / \mathrm{sec}$ and its different directions

(in eight rhumbles): $\mathbf{a}-0^{\circ}(\mathrm{E}) ; \mathbf{b}-45^{\circ}(\mathrm{NE}) ; \mathbf{c}-90^{\circ}(\mathrm{N}) ; \mathbf{d}-135^{\circ}(\mathrm{NW}) ; \mathbf{e}-180^{\circ}(\mathrm{W})$;

$$
\mathbf{f}-225^{\circ}(\mathrm{SW}) ; \mathbf{g}-270^{\circ}(\mathrm{S}) ; \mathbf{h}-315^{\circ}(\mathrm{SE}) \text {. }
$$

The number of local circulation zones within the calculated area, their size, speed and direction of currents (especially in shallow areas) depend on the wind direction. The choice of direction $225^{\circ}$ for performing calculations is related to the maximum repeatability of winds in this direction during the dredging period.

Calculations have shown that the velocities of currents in the central part of the water area during dredging operations will decrease, and at various stages of dredging, the spatial structure of the water will be restructured (with some displacement of the water circulation along the boundary of the works towards the open water area) (Fig. 3). 

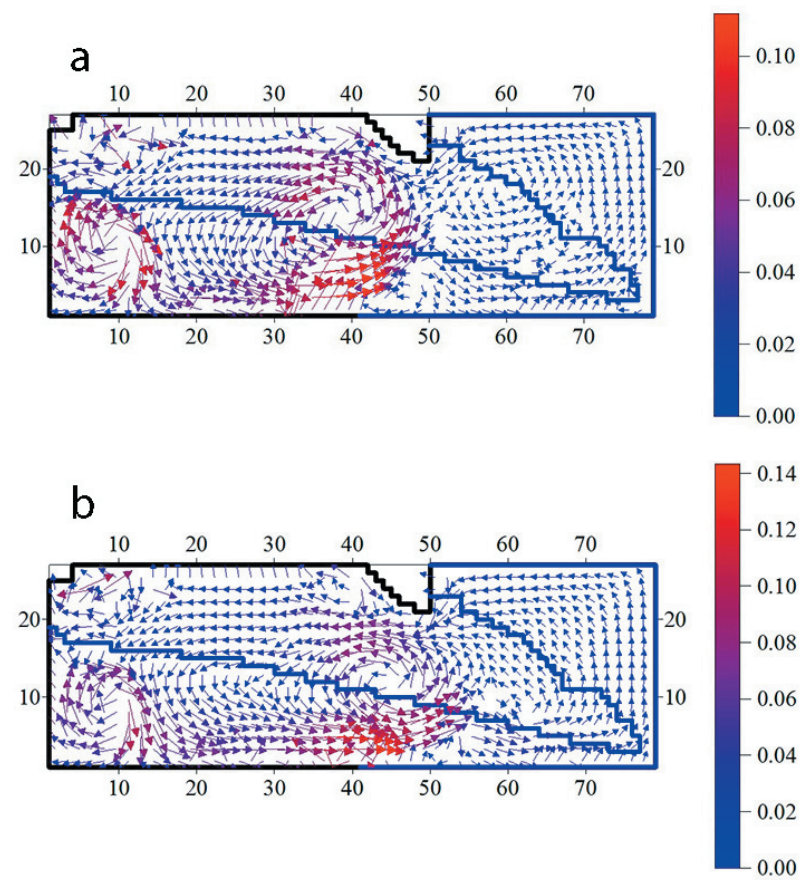

Fig. 3. Calculated flow fields $(\mathrm{m} / \mathrm{sec})$ in the dredging area at a wind speed of $6 \mathrm{~m} / \mathrm{sec}$ and directions of $225^{\circ}(\mathrm{SW})$ for different work stages: $\mathbf{a}$ and $\mathbf{b}-$ up to mark -7.8 and $-10.9 \mathrm{~m}$ respectively.

\section{Spatio-temporal structure of turbidity fields: estimation of areas and volumes of AWT zones}

Calculations of the fields of distribution of SM concentrations were carried out for the area of dredging at an average long-term wind speed of $6 \mathrm{~m} / \mathrm{sec}$ and its directions $225^{\circ}(\mathrm{SW}), 270^{\circ}(\mathrm{S}), 180^{\circ}(\mathrm{W})$ and $45^{\circ}(\mathrm{NE})$. Fig. 4 shows the distribution of $\mathrm{SM}$ concentrations and the position of the AWT zone at the SM concentration $>50 \mathrm{mg} / \mathrm{L}$ on different stages of dredging at typical values of the wind regime indicators - wind speed $6 \mathrm{~m} / \mathrm{sec}$ and direction $225^{\circ}(\mathrm{SW})$. An analysis of the obtained distribution of the AWT zones shows that:

- Fig. 4a (stage 1): the boundary of the AWT zone divides the entire work area in half; the average concentration of SM in the AWT zone is $11.9 \mathrm{~g} / \mathrm{L}$; for one day, the area of this zone was 35.16 hectares, and the volume of water in it is $1758255.5 \mathrm{~m}^{3}$; for the entire period of this stage ( 4 days), the area of the AWT zone will increase to 140.66 hectares, and the volume of water to $703302.0 \mathrm{~m}^{3}$;

- Fig. 4b (stage 1): for the period of work, the AWT zone actually goes beyond the dredging area; the average SM concentration in the AWT zone is $13.1 \mathrm{~g} / \mathrm{L}$; for a day, the area of the AWT zone was 25.35 hectares, and the water volume $-1267578.5 \mathrm{~m}^{3}$.

Comparison of the calculations (Figs. $4 \mathrm{a}, \mathrm{b}$ ) shows that the average SM concentrations in the AWT zone differ little (11.9 and $13.1 \mathrm{mg} / \mathrm{L})$, and the area of the AWT zones in the first variant is higher by $\sim 10$ hectares! Thus, the areas and volumes of the AWT zones depend substantially on the wind regime.

- Fig. 4c (stage 2): the AWT zone for the period of work occupies almost the entire area of the dredging and the open part of the water area; the average SM concentration in the AWT zone is $18.1 \mathrm{~g} / \mathrm{L}$; for one day, the area of the AWT zone has grown to 51.11 hectares, and the water volume - up to $3577656.6 \mathrm{~m}^{3}$, and for the entire period of this stage 
Podgorny K.A., Leonov A.V.

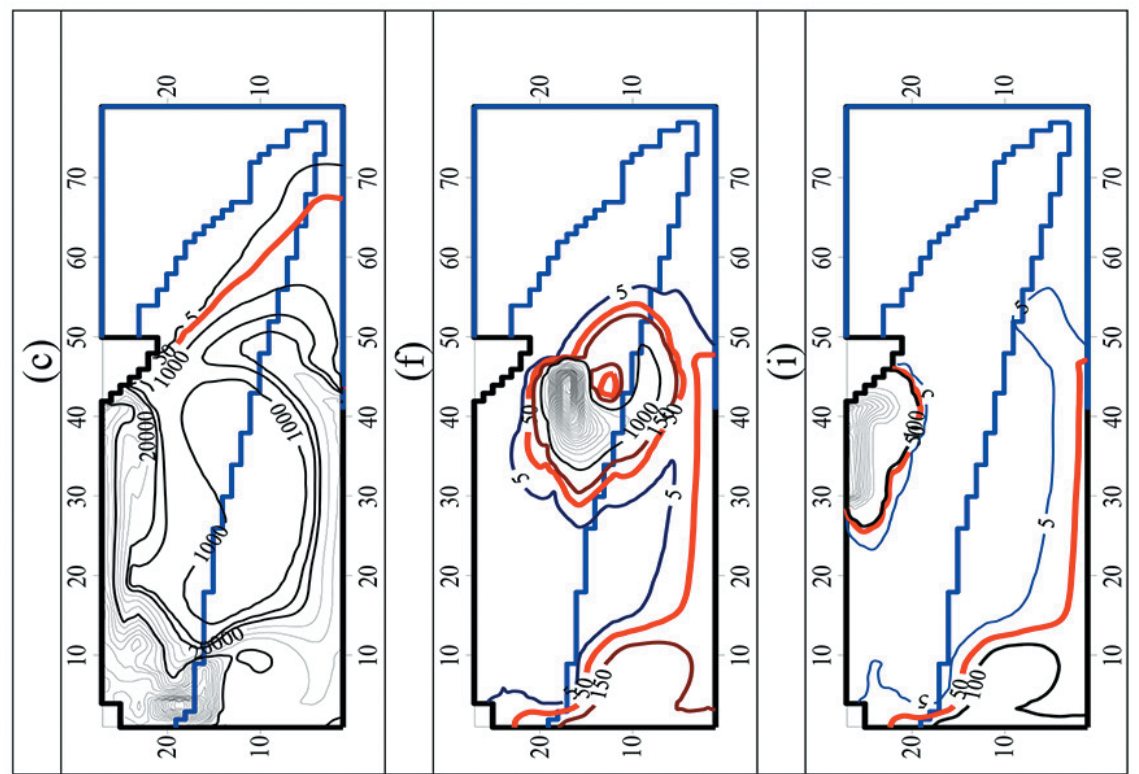

Æ. ฮี (ิ)

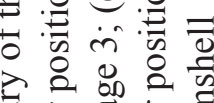

预芯芯芯

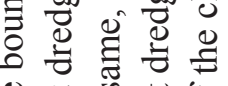

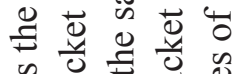

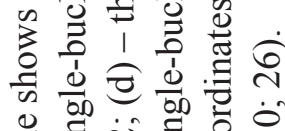

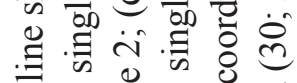

ฮี

눙

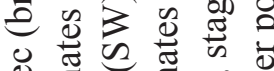

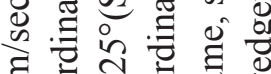

घิ ปิ

苛

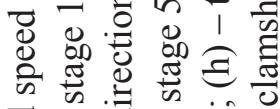

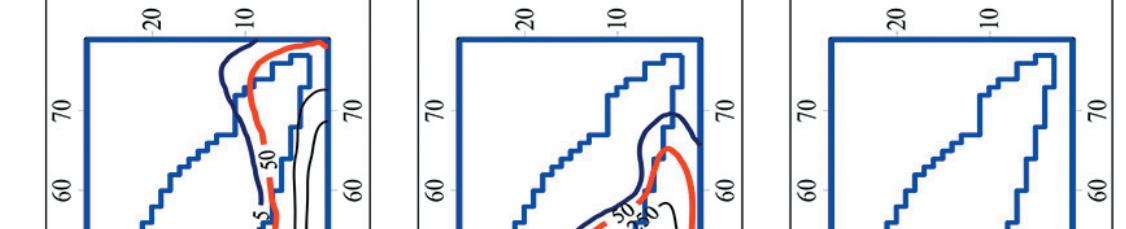

믛

उ

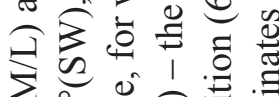

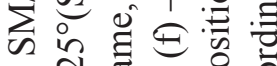

๒

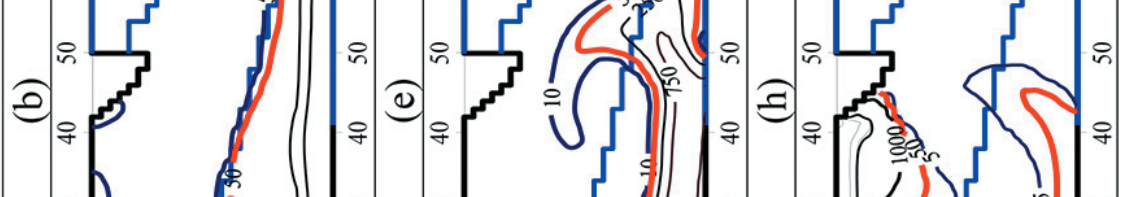

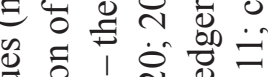

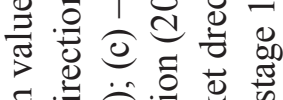

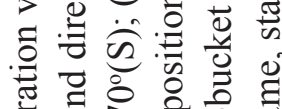

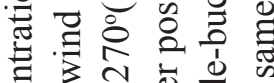

ग प

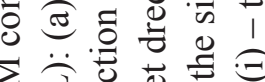

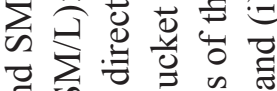

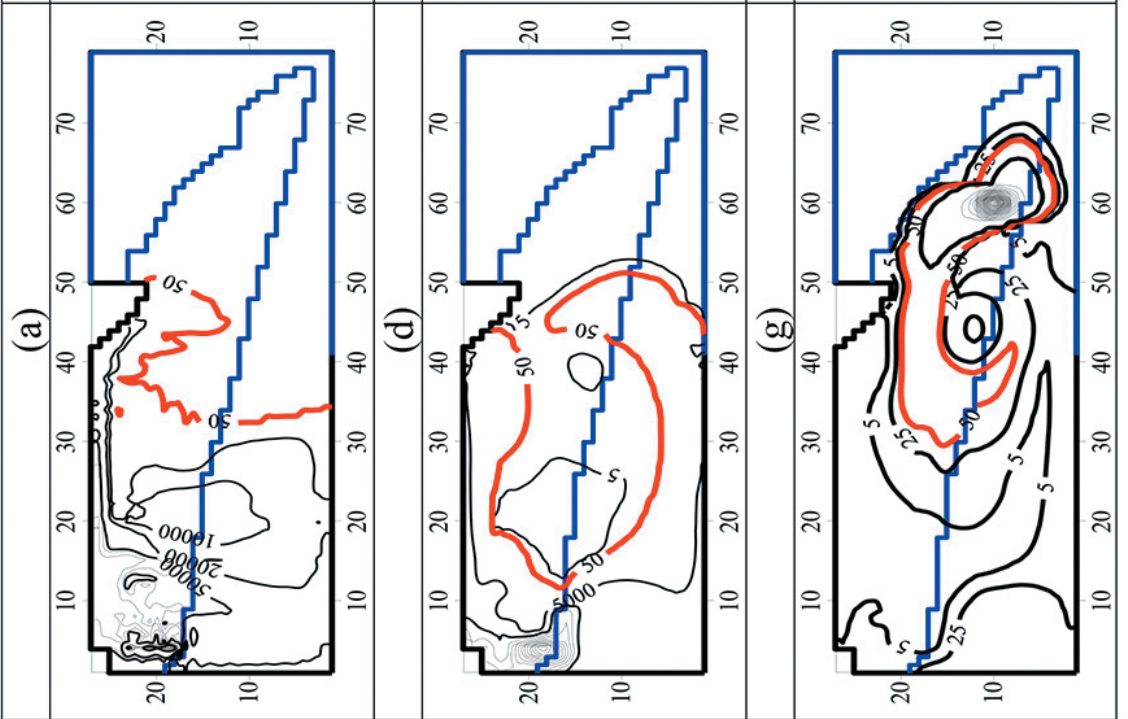

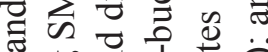

๑ b

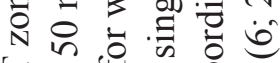

乡ᄉि

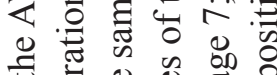

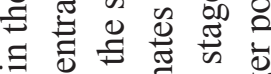

के

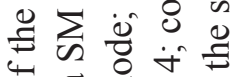

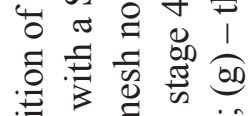

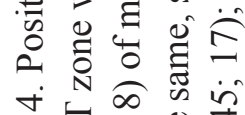

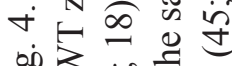

兽令莳 
(6.1 days) the AWT zone will occupy an area of 311.77 hectares with a water volume of $21823705.3 \mathrm{~m}^{3}$;

- Fig. 4d (stage 3): the AWT zone for the period of work is located in the coastal part of the dredging area and on its western side it enters to open waters, and the most part of the dredging area remains outside the AWT zone (except for a small section in the central part of the area); the average SM concentration in the AWT zone is $1.9 \mathrm{~g} / \mathrm{L}$; for one day, the area of the AWT zone will be 28.25 hectares, and the water volume $1977325.0 \mathrm{~m}^{3}$; for the entire period of dredging ( 0.4 day), the area of the AWT zone will increase 11.30 hectares, and the water volume - up to $790930.0 \mathrm{~m}^{3}$;

- Fig. 4e (stage 4): the most part of the dredging area is out of contact with the AWT zone (except for two small sections - the work area of the dredger (coordinates 20; 20) and the eastward-shifted section in the center of the entire dredging area; the average SM concentration in the AWT zone $-0.92 \mathrm{~g} / \mathrm{L}$; for one day, the area of the AWT zone will be 26.29 hectares, and the water volume of water $-2760447.9 \mathrm{~m}^{3}$; for the entire period of dredging (6.5 days), the area of the AWT zone will increase 170.89 hectares, and the water volume - up to $17942911.4 \mathrm{~m}^{3}$;

- Fig. $4 \mathrm{f}$ (stage 5): the AWT zone remains in the central part of the work area at the site of the dredger (coordinates $45 ; 17$ ); the average SM concentration in the AWT zone is $0.52 \mathrm{~g} / \mathrm{L}$; for one day, the area of the AWT zone will be 19.56 hectares, and the water volume $-2054080.4 \mathrm{~m}^{3}$; for the entire period of dredging (7.4 days), the area of the AWT zone will increase 144.76 hectares, and the water volume - up to $15200195.0 \mathrm{~m}^{3}$;

- Fig. 4g (stage 7): when the dredging area is shifted to the east (coordinates 60, 10), the boundaries of the AWT zone substantially increase and cover the greater part of the center of the dredging area; the average SM concentration in the AWT zone is $1.57 \mathrm{~g} / \mathrm{L}$; for one day, the area of the AWT zone will be 9.72 hectares, and the water volume $-1020074.0 \mathrm{~m}^{3}$; for the whole period of dredging works (23.9 days), the area of the AWT zone will increase by 232.19 ha, and the water volume - up to $24379768.6 \mathrm{~m}^{3}$;

- Fig. 4h (stage 10): the position of the AWT zone depends on the initial position of the dredger (coordinates $6 ; 26$ ) and occupies a portion of a coastal part of the dredged region; and along the western border of water area, the AWT zone penetrates into open waters; to the east from the center of the dredging region, the AWT zone does not penetrate; the average SM concentration in the AWT zone is $29.03 \mathrm{~g} / \mathrm{L}$; for one day, the area of the AWT zone will be 21.19 hectares, and the water volume - $1483312.6 \mathrm{~m}^{3}$; for the entire period of dredging ( 0.9 day), the area of the AWT zone will be 19.07 hectares, and the water volume $-1334981.3 \mathrm{~m}^{3}$.

- Fig. 4i (stage 11): the position of the AWT zone is determined by the starting point of the dredger (coordinates 30; 36); in the dredging region, the AWT zone occupies coastal part, and a second section of the AWT zone formed outside the dredging area in the open areas of the western boundary of water area; the average SM concentration in the AWT zone is $1.73 \mathrm{~g} / \mathrm{L}$; for one day, the area of the AWT zone will be 12.16 hectares, and the waster volume $-1277035.2 \mathrm{~m}^{3}$; for the entire period of dredging works (6.8 days), the area of the AWT zone will increase to 82.70 hectares, and the water volume$8683839.4 \mathrm{~m}^{3}$. 
Thus, under the typical wind regime (wind speed $6 \mathrm{~m} / \mathrm{sec}$, direction $225^{\circ} \mathrm{SW}$ ), the following values of the parameters characterizing the formation of the AWT zone are revealed:

- the values of the indicators (mean SM concentration in the work region, areas and volumes of the formed AWT zones) in a greater extent depend on the type of extracted bottom sediments and the site of the dredging work, and in a lesser extent - on the duration of work at a particular stage;

- the highest mean SM concentration (29.03 g SM/L) was obtained in the stage 10 (works with the sand of medium-scale in the coastal zone at a total duration of 0.9 days); elevated concentration ( $18.1 \mathrm{~g} \mathrm{SM} / \mathrm{L}$ ) - on the stage 2 (works with heavy hard clay in the coastal zone for 6.1 days); reduced concentration $(0.52 \mathrm{~g} \mathrm{SM} / \mathrm{L}) \mathrm{d}$ - on the stage 5 (works with sand silty in the middle part of the area for 7.4 days);

- generated during one day of dredging operations, the greatest area and volume of the AWT zones (51.11 ha and $3577656.6 \mathrm{~m}^{3}$ respectively) were prepared in the stage 2 . It should be also noted certain stages with increased area and volume of AWT zones - the stage $1\left(35.16\right.$ hectares and $\left.1758255.5 \mathrm{~m}^{3}\right)$ at works with sand dusty in the coastal zone (coordinates 4,18 ) for 4 days; conditionally, the stage $3\left(28.25\right.$ ha and $1977325.0 \mathrm{~m}^{3}$ ) when working with medium-sized sand on the border with open waters (coordinates 20, 20 ) for 0.4 day; the stage 4 (26.25 hectares and $2760447.9 \mathrm{~m}^{3}$ at works with loam in the central part of the area (coordinates 20,40) for 6.5 days. The lowered values of the area and volume of the AWT zone were fixed at stage $7\left(9.72\right.$ ha and $\left.1020074.0 \mathrm{~m}^{3}\right)$ during works with heavy hard clay at the boundary with the open water area (coordinates 10,60) for 23.9 days;

- the largest areas and volumes of the AWT zones (311.77 ha and $21823705.3 \mathrm{~m}^{3}$ respectively) formed during the entire stage of dredging operations were obtained on the stage 2 , and the elevated values (232.19 ha and $\left.24379768.6 \mathrm{~m}^{3}\right)$ - on the stage 7 . The lower values of the area and volume of the AWT zone $\left(82.70\right.$ ha and $\left.8683839.4 \mathrm{~m}^{3}\right)$ were obtained on the stage 11 when working with medium-sized sand and loam in the coastal part (coordinates 30,36 ) for 6.8 days.

\section{Calculation of the layer thickness of the sediment falling to the bottom during dredging}

The thickness of the layer $h_{\text {sed }}$ of precipitations deposited to the bottom as well as the total volume of sediments entering on the bottom of the water body, $V_{\text {sed }}$, and the volumetric weight of the sediments in a state of natural structure, $\gamma$, are calculated from equations (9)-(11) (Appendix). The area of precipitations deposited to the bottom, $S_{\text {sed }}$, is estimated from the value of the water area with an additional $(>50 \mathrm{mg} / \mathrm{L})$ concentration of SM with particles $<0.14 \mathrm{~mm}$ in size. The results of the calculations are given in Table 5 . 
Океанологические исследования. 2020. Том 48. № 2. С. 107-134

政

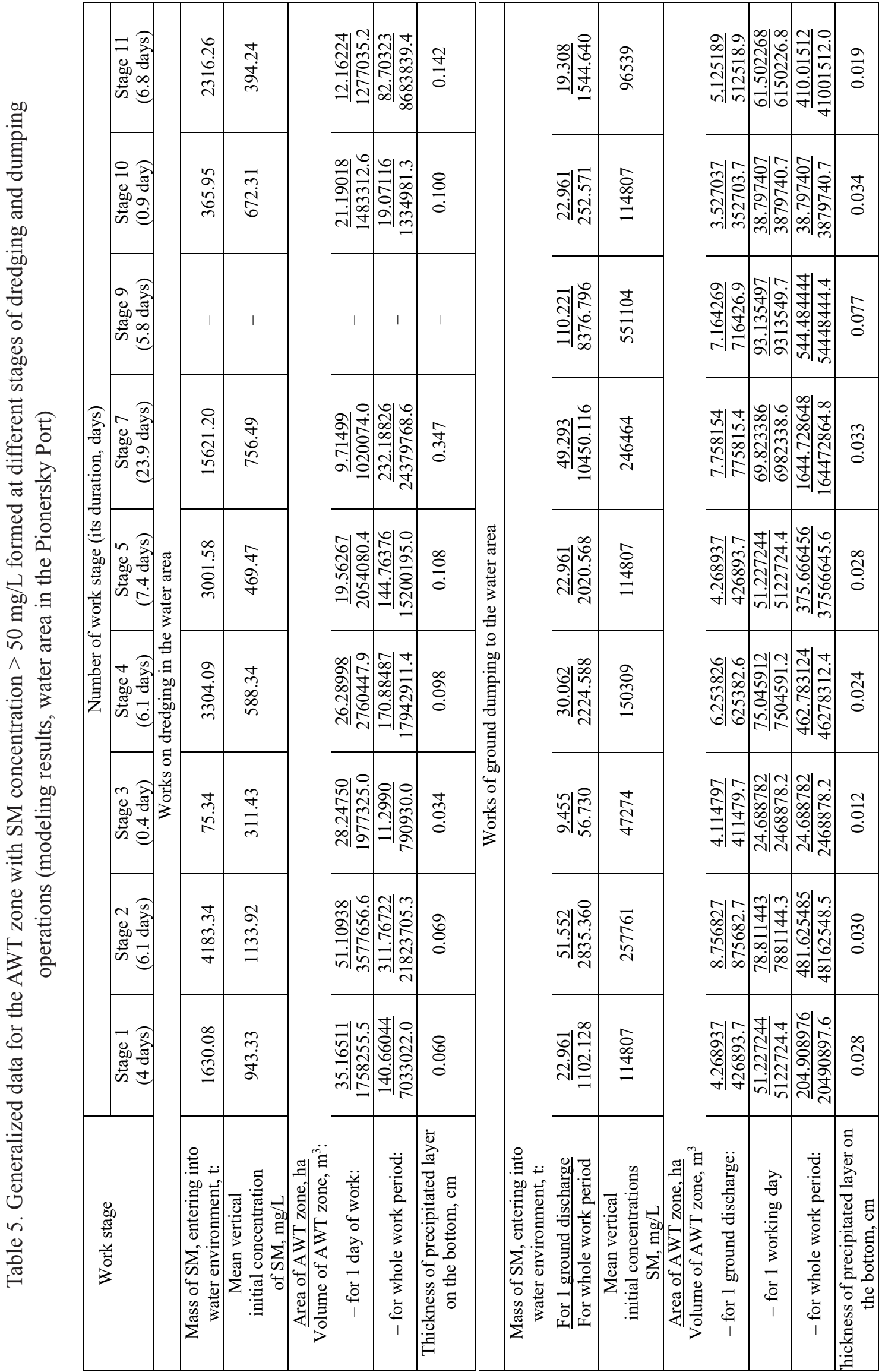


Calculations show that for stages 1-3 the layer of particles of SM falling to the bottom during bottom dredging within the AWT zone is insignificant in thickness $(0.034$ $0.069 \mathrm{~cm})$, for stages $4,5,10,11$ - it is within $(0.098-0.142 \mathrm{~cm})$ and for stage 7 - the largest $(0.347 \mathrm{~cm})$. The total thickness of the layer of precipitated SM for the period of work at all stages of dredging will be $0.958 \mathrm{~cm}$ (or no more than $1 \mathrm{~cm}$ ) (Table 5).

\section{Calculations to characterize the consequences of sediment dumping in an underwater dump}

When dumping of sediments in the underwater dump, a large zone of turbidity of water (due to the presence of SM in it) is formed on the water surface, and this amount of SM gradually settles down and eventually accumulates at the bottom. The main initial data for determining the parameters of the water turbidity spot during overfilling are $W_{s}$ (the effective sedimentation rate of SM, its calculation was performed earlier) and $G$ (the mass of the sediment discharged during dumping into the water body and passing to the suspended state when it enters to the water). Sediment mass $G(t)$ is calculated according to equation (12) (Appendix).

The sediments are dumped into the underwater dump for $\sim 10 \mathrm{~min}$. At the same time, the scow (or hold dredger), participating in the work, are moved across the water area and it contributes to a faster and full discharge of sediment and "washing" of the hold. The sediment reset is made not "point-wise", but distributed - in several nodes of the grid. When calculating the distribution of SM concentrations in the water area, the condition is fulfilled that at a speed of movement of the scow and a self-hauling dredger with a load ( $\sim 100 \mathrm{~m} / \mathrm{min})$, the sediment is dumped in 20 nodes of the grid. Its step has been taken to be constant in directions and is $50 \mathrm{~m}$. Taking this into account, at each stage the vertical averages the initial SM concentrations will be estimated based on the calculated values of $G$.

We accept the following general values for all calculations: $k_{1}=0.1$ (or $10 \%$ ), maximum capacity of the hold: in the scow $V=500 \mathrm{~m}^{3}$ (on the ground $-500 \times 0.8=$ $400 \mathrm{~m}^{3}$ ); for a self-discharging dredger (loading rate) $V=1200 \mathrm{~m}^{3}$ (on a ground $1200 \times 0.7=840 \mathrm{~m}^{3}$ ), the volume weight of water $\gamma_{W}=1.0 \mathrm{t} / \mathrm{m}^{3}$. The average depth in the dumping area of the soil is $10 \mathrm{~m}$.

From Tables 1 and 3, we choose the values of the other parameters for the calculations for each step. For example, for the work stage 1, the following parameter values are accepted for the calculations: $P=0.392, k_{1}=0.1 ; \gamma=1.92, \gamma_{S}=2.69 \mathrm{t} / \mathrm{m}^{3}$, and the calculation of the $G$ value (the mass of SM entering to the water for one ground discharge) is:

$$
G=0.392 \times 0.10 \times 400 \times 2.69 \times \frac{1.92-1.0}{2.69-1.0}=22.961 t(\text { or } 22961458 \mathrm{~g}),
$$


and the total discharged mass of SM for the entire stage of work is obtained, taking into account the total number of discharges:

$$
G_{t o t}=22.961 \times 48=1102.128 t
$$

(where 48 is the total amount of sediment discharges at the stage of works 1).

Then calculate the value of the initial mean SM concentration:

$$
\left.\mathrm{SM}=22962458 \mathrm{~g} /\left(\left(1 \mathrm{~m}^{2} \times 10 \mathrm{~m}\right) \times 20\right)=114807 \mathrm{~g} / \mathrm{m}^{3} \text { (or } 114807 \mathrm{mg} / \mathrm{L}\right) .
$$

Similarly, we calculate the values of $G, G_{t o t}$, and the initial mean concentrations of SM according to the data for all stages of the work, and we include the results in the final Table 5.

At the stages of works 6 and 8 the self-hauling bilge pump "Glenford" is used; therefore, there is no sediment loss due to dredging ( and $k=0$ and $G=0$ ), and there is no formation of an AWT zone.

\section{Parameters of the grid area for simulating the sediment discharges into an underwater dump}

The grid area for calculation of sediment dumping into the underwater dump is the area with the total number of $41 \times 41$ nodes (both 41 nodes along horizontal OX and vertical OY axes). Spatial grid steps, $h_{x}$ and $h_{y}$, with respect to the spatial coordinates $x$ and $y$ are chosen to be constant (on $50 \mathrm{~m}$ ). The dimensions of the design area are $40 \times 50 \mathrm{~m}=2000 \mathrm{~m}$ along the OX and OY axes. The area of one cell in the calculation area is $50 \times 50=2500 \mathrm{~m}^{2}$, and the total area of the entire design area is $40 \times 40 \times 2500=$ $4000000 \mathrm{~m}^{2}$ (400 ha). Since neither the values of the current velocities nor the time course of the level at the open boundaries of observations are unknown, zero values of the free surface level will be given at the calculations.

The maximum depth $H_{\max }$ within the grid area to the water area of the dredging is $15.8 \mathrm{~m}$, and time step $\tau$ depends on the grid steps on the spatial coordinates $\Delta s$. At the choosing of the value $\tau$, it is necessary to ensure the Courant-Friedrichs-Levy-criterion of the observation stability for computations of $\tau$ estimated by equation (4) (Appendix). Thus, when performing the numerical integration of the system of hydrodynamic equations, the time step $\tau$ will be taken as

$$
<\frac{50}{\sqrt{9,81 \times 15,8}}=4,02 \mathrm{sec} .
$$

For the convenience of calculations, the time step $\tau$ will take 4 sec. The same step $\tau$ will use at the numerical integration of the system of evolution equations of advection and turbulent diffusion in calculations of the SM transport in the dredging region.

Changes of the spatial structure of currents in the area of sediment dumping are shown in Fig. 5 with an average annual wind speed of $6 \mathrm{~m} / \mathrm{sec}$ and with the most frequent repeatability of its direction $-90^{\circ}(\mathrm{N}), 180^{\circ}(\mathrm{W})$, and $225^{\circ}(\mathrm{SW})$. The most complex 


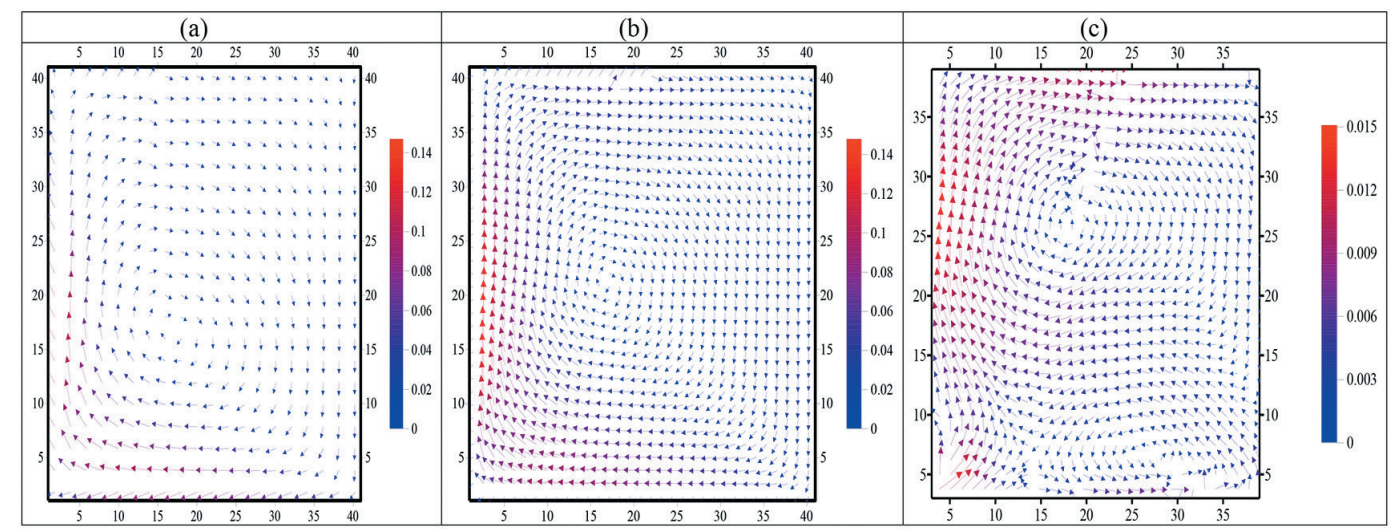

Fig. 5. Calculated flow fields $(\mathrm{m} / \mathrm{sec})$ in the area of ground dumping in the underwater dump at wind speed of $6 \mathrm{~m} / \mathrm{sec}$ and different wind directions: $\mathbf{a}-90^{\circ}(\mathrm{N}) ; \mathbf{b}-180^{\circ}(\mathrm{W}) ;(\mathrm{W}) ; \mathbf{c}-$ $225^{\circ}$ (SW). Here and in Fig. 6, the vertical axis OY and the horizontal axis OX include 41 and 41 grid nodes (the spatial step along the grid $h_{x}$ and $h_{y}$ is constant and equal to $50 \mathrm{~m}$; the total length of the OY axis $=2000 \mathrm{~m}$, OX axis $=2000 \mathrm{~m}$ ).

picture of the currents in the work area occurs at the wind directions $225^{\circ}(\mathrm{SW})$ with the formation of water circulations in the central zone of the area (coordinates 26, 19) and at its boundary $(7 ; 26)$, as well as the frontal zone of currents $(5 ; 14)$. We will orient ourselves to this flow pattern for further calculations of the formation of the AWT zones that arise during sediment dumping at different work stages.

The areas of AWT zones with a SM concentration of $50 \mathrm{mg} / \mathrm{L}$ were estimated in the Surfer software package (v. 8.01) according to the simulation data obtained every 6 minutes of model time. For subsequent assessments of the damage, the time of formation of the largest area of the spot was selected from the entire time series of values of such areas, while maintaining an SM concentration of $\geq 50 \mathrm{mg} \mathrm{SM} / \mathrm{L}$. After that, the spot of SM will only decay due to the processes of SM sedimentation and dilution. Fig. 6 illustrates examples of corresponding calculations of the position of AWT spots and SM concentrations $(\mathrm{mg} / \mathrm{L})$ for dumping various sediments at a wind speed of $6 \mathrm{~m} / \mathrm{sec}$ and its direction $225^{\circ}(\mathrm{SW})$ for different stages of dredging, Analysis of the results shown in Fig. $6 \mathrm{a}-\mathrm{z}$ allows to quantify the main indicators of the emerging AWT zones (the vertical averages of the initial SM concentrations, the values of the areas and the volumes of the AWT zones for a single ground discharge, per one day of work and for the entire duration of work at each stage (Table 5).

In order to characterize the intensity of the impact of sediment dumping operations, we shall construct the number line series showing the reduction of the indices for one fault, per one day and for the entire duration of the work at each stage (areas $S$ and volumes $V$ ) of the formed AWT zones (with a SM concentration $>50 \mathrm{mg} / \mathrm{L}$ ). Thus, the values of $S(\mathrm{ha}) / V\left(\mathrm{~m}^{3}\right)$ per sediment discharge at different stages of work, which mainly reflect the sediment properties, decrease in the following order: 8.757/875682.7 (stage 2) >7.758/775815.4 (stage 7) >7.164/716426.9 (stage 9) $>6.254 / 625382.6$ (stage 4$)$ 

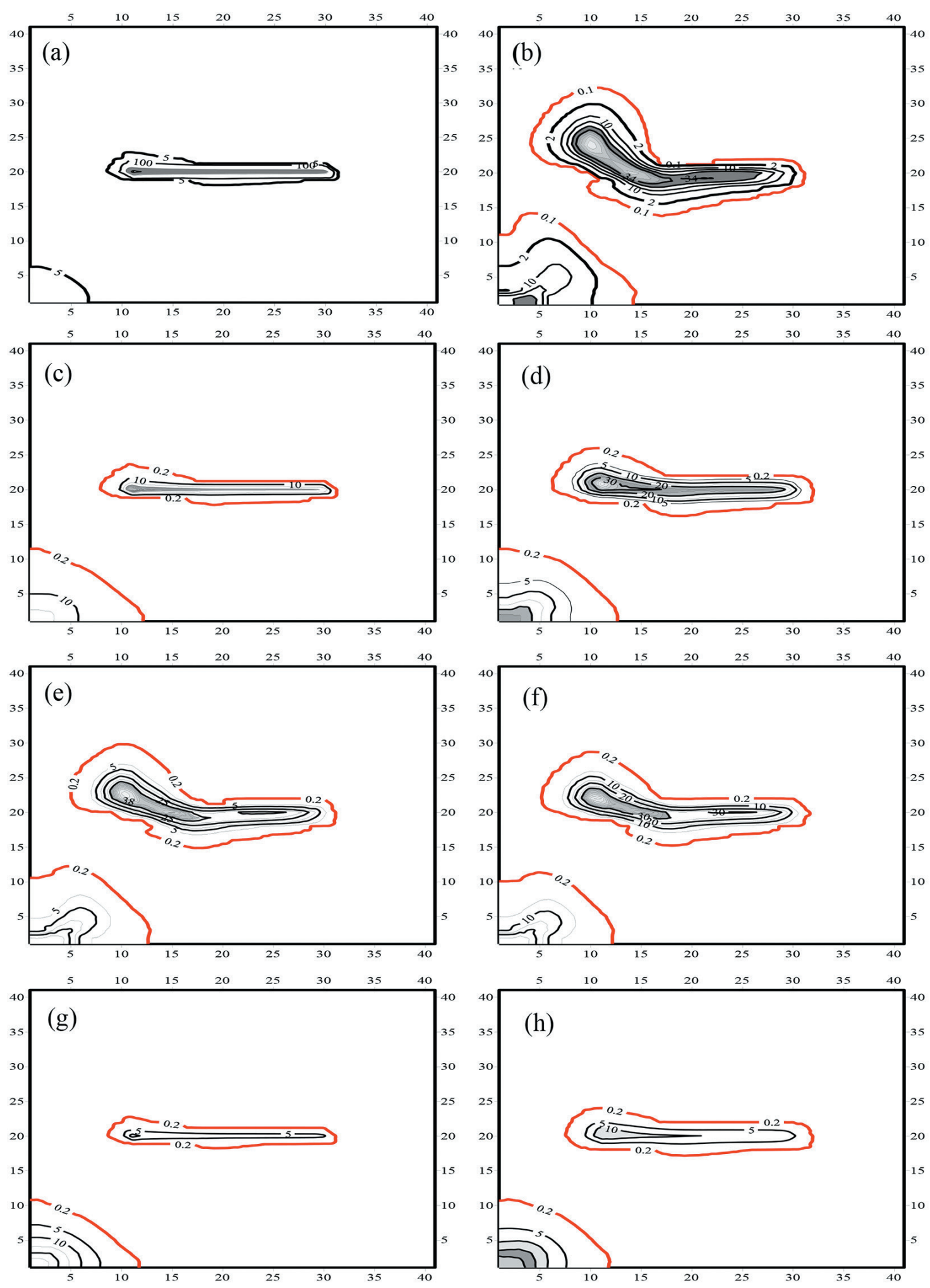

Fig. 6. Position of the spot in the AWT zone and SM concentration values $(\mathrm{mg} / \mathrm{L})$ at a wind speed of $6 \mathrm{~m} / \mathrm{sec}$ and its direction of $225^{\circ}(\mathrm{SW})$ after ground dumping in the submarine dump at different work stages: (a) - stage 1: after $0.5 \mathrm{~h}$; (b) - stage 2: 4.3 hours; (c) - step 3: 0.7 hours;

(d) - stage 4: 1.7 hours; (e) - stage 7: 3.4 hours; (f) - stage 9: 2.9 hours; (g) - stage 10: 0.6 hours; (h) - stage 11: 1.0 hours. 
$>5.125 / 512518.9($ stage 11 ) $>4.269 / 426893.7$ (stages 1 , and 5) $>4.115 / 411479.7$ (stage 3) $>3.527 / 352703.7$ (stage 10). According to these data, the work with clay particles enters the beginning of the series.

The sequence of values varies slightly for one day of work - 93.136/9313549.7 (stage 9) $>78.811 / 7881144.3$ (stage 2) $>75.046 / 7504591.2$ (stage 4) $>69.823 / 6982338.6$ (stage 7) $>61.502 / 6150226.8($ stage 11) $>51.227 / 5122724.4($ stages 1 , and 5) $>38.797 / 3879740.7$ (stage 10) $>24.689 / 2468878.2$ (stage 3) - works with sand of medium size of the second group, clay particles and loam are in the beginning of the series.

Finally, for the entire period of the work, the sequence of values $S$ (ha) $/ V\left(\mathrm{~m}^{3}\right)$ is as follows: $1644.729 / 164472864.8$ (stage 7-23.9 days) $>544.484 / 54448444.4$ (stage 9-5.8 days) $>481.626 / 48162548.5$ (stage $2-6.1$ days) $>462.783 / 46278312.4$ (stage 4 6.1 days) $>410.015 / 41001512.0$ (stage 11-6.8 days) $>375.667 / 37566645.6$ (stage 57.4 days) $>204.909 / 20490897.0$ (stage $1-4$ days) $>38.797 / 3879740.7$ (stage 10-0.9 day) $>24.689 / 2468878.2$ (stage 3-0.4 day), and their final position depends mainly on the duration of the work in separate stages.

The distribution of the average SM concentrations, $\mathrm{mg} / \mathrm{L}$, characterizes the following series: 551104 (stage 9) >2577619 (stage 2) >246464 (stage 7) >150309 (stage 4) $>114807$ (stages 1, 5, and 10) $>96539$ (stage 11) $>47274$ (stage 3) which reflects the combined effect of factors affecting on the final distribution in water areas of ground particles entering into the water body during its dumping.

The results of mathematical modeling simulation show that at deposition rates of $\mathrm{SM}>0.003 \mathrm{~m} / \mathrm{sec}$, the lifetime of AWT zones with a concentration of SM $>50 \mathrm{mg} \mathrm{L}$ is on average 1-2 hours. For clay fractions, that have reduced deposition rates $(\sim 0.0006-$ $0.0007 \mathrm{~m} / \mathrm{sec}$ ), the time of existence of AWT spots is much higher (up to 5-8 hours). The duration of the existence of the AWT spot, in addition to the deposition rate of SM, is also affected by the depth of the sea and the specific wind situation at a given time, as well as the presence of stirring up the botom sediments which serves as an additional source of SM input to the water environment.

It should be noted that the formations of the secondary AWT zones are clearly visible in Fig. $6 \mathrm{a}-\mathrm{h}$ on the boundary of the water work area (the lower left section) that are not directly related to dumping operations in the central part of the water area. These secondary zones are formed and stably exist when winds are strong enough for the disturbing of the bottom sediments and the nature of the currents in the shallow section of the ground dumping zone. Therefore, it is undesirable to carry out discharge of sediment at depths $<5-7 \mathrm{~m}$. 


\section{Calculation of the layer thickness of the sediment falling to the bottom during dredging}

The thickness of the layer of precipitation falling to the bottom as a result of the dumping of the sediment in the underwater dump is estimated by the same procedure as in the case of dredging. The results of the corresponding calculations for all work stages are given in Table 5 .

As a result of ground losses during its dumping into the underwater marine dump, the layer of precipitates deposited to the bottom in the AWT zones will be the smallest in stages $3(0.012 \mathrm{~cm})$ and $11(0.019 \mathrm{~cm})$ with mean values in the range $(0.024-0.034 \mathrm{~cm})$ during stages $4,1,5,2,7$, and 10 . The greatest thickness of precipitations $(0.077 \mathrm{~cm})$ will be formed at the stage 9, and the total thickness for all work stages will be $0.285 \mathrm{~cm}$ (that is, does not exceed $0.3 \mathrm{~cm}$ ).

\section{CONCLUSION}

An example of the application of the developed SM-model for estimating the consequences of dredging and construction work and, in particular, a series of calculations for the characterization of the formation of AWT zones (in a case of creating a terminal in the Pionersky Port, Kaliningrad Region). Similar calculations are carried out on the available technical data to obtain the quantitative indices necessary for compiling an AIWES for a specific work, and in this case - the works on improving and modernizing the infrastructure of the territory of a particular port and its individual structures.

The main characteristics of the works: the total volume of dredging sediments $-1252450 \mathrm{~m}^{3}$, the total dredging area $-30.61 \mathrm{ha}$, the total volume of ground for the modernization of the territories $-264.600 \mathrm{~m}^{3}$ (excluding the volume of ground for the construction of the GTS), the total amount of required ground for construction works - 961.7 thousand $\mathrm{m}^{3}$ of sand ground. Part of the ground recovered during dredging (in particular, sand of medium size with the total volume of its removal $105,850 \mathrm{~m}^{3}$ ) will be used in the construction of the GTS, the unused ground will be transported outside the port and discharged into the marine underwater dump. Works on dredging and dumping of ground should be carried out from January to May, and also in August (as a whole during 11 work stages on which the corresponding types of work will be carried out a round the clock).

Calculations with the help of the developed SM-model have shown that the formed areas of water pollution (or AWT zones) for each working day and different types of grounds can vary from 9.7 to 51.1 ha, and the volumes of these zones vary from 1020074.0 to $3577656.6 \mathrm{~m}^{3}$ at the dredging works. The average SM concentrations in the AWT zones vary from 519.2 to $29031.4 \mathrm{mg} \mathrm{SM} / \mathrm{L}$. For the entire period of planned dredging works within the water area, the total area of pollution for each stage of work will vary from 
11.3 to 311.8 ha, and their total area will be 1113.33 ha. The total volume of contaminated water for each stage of dredging will vary from 790930.0 to $24379768.6 \mathrm{~m}^{3}$, and their total volume will be $72809585 \mathrm{~m}^{3}$.

Calculations showed that the resulting areas of the AWT zone during the discharges of different types of grounds for each working day can vary from 38.8 to 93.1 hectares, and the volumes of these zones - from 2468878.2 to $9313549.7 \mathrm{~m}^{3}$ at the dumping the ground in a marine underwater dump. The average initial SM concentration in these zones varies from 47,274 to 551,104 mg SM/L. For the entire period of planned dumping operations, the total contamination area for each work stage will vary from 24.7 to 1644.7 ha, and the total area of the AWT zones will be 4187.7 ha. The total volume of contaminated water in the AWT zones for each stage of dredging works will vary from 20490897.6 to $164472864.8 \mathrm{~m}^{3}$, and the total volume of AWT zones will be $418769844 \mathrm{~m}^{3}$.

The results of mathematical modeling show that the total thickness of the precipitation layer over the entire working period will not exceed $1 \mathrm{~cm}$ of ground losses in dredging operations on the terminal water area. As a result of ground loss during its dumping into the underwater marine dump, the total thickness of the precipitation layer over the entire period these works will not exceed $0.3 \mathrm{~cm}$.

The results of mathematical modeling simulation show that at sedimentation rates $>0.003 \mathrm{~m} / \mathrm{sec}$, the lifetime of a spot in AWT zones with an SM concentration $>50 \mathrm{mg}$ $\mathrm{SM} / \mathrm{L}$ is an average of 1-2 hours. The time of existence of spots in the AWT zones formed by clay fractions having deposition rates $(\sim 0.0005-0.0007 \mathrm{~m} / \mathrm{sec})$, increases to $5-8$ hours.

Acknowledgments: Financial support for research in AtlantNIRO (Kaliningrad) was provided during the implementation of the project for the Construction of the International Sea Terminal (IST) in Pionersky, Kaliningrad region, and in the Shirshov Institute of Oceanology RAS (Moscow) - in the frame of theme № 0128-2019-0011 «Interaction of biogeospheres in the World ocean».

\section{APPENDIX}

\section{Additional equations used in the calculations}

$$
V_{h}=V_{10} \cdot(0,233+0,656 \cdot \lg (h+4,75))
$$

- the Helman's equation for calculation of wind speed, $\mathrm{m} / \mathrm{s}$, to the installation height instruments for meteorological observations $10 \mathrm{~m}$; where $V_{h}$ and $V_{10}$ are, respectively, the wind speed, $\mathrm{m} / \mathrm{s}$, at a height of $h$ and $10 \mathrm{~m}$ above sea level;

$$
W_{S}=\frac{\sum_{n=1}^{M}\left(W_{s}\right)_{n} \times P_{n}}{P}
$$

- equation for calculating the effective sedimentation velocity, $\mathrm{cm} / \mathrm{s}$, of suspended particles 
with size $\leq 0.1 \mathrm{~mm} ;\left(W_{S}\right)_{n}$ is the hydraulic size of the individual $n$-th particle fractions, $\mathrm{cm} / \mathrm{s}$, depending on the temperature; $P_{n}$ and $P$ - respectively the weight content in the soil of individual $n$-th particles with a size $\leq 0.1 \mathrm{Mm}$ and their total content is fractions of 1 ;

$$
q=\left(P \cdot k \cdot Q \cdot \gamma_{S} \cdot \frac{\gamma-\gamma_{W}}{\gamma_{S}-\gamma_{W}}\right) / 3600
$$

- equation for calculating the soil flow rate $q(\mathrm{t} / \mathrm{s})$, the turning into a suspended state during dredging works; $P$ is total weighted content in the soil of particles with a size $\leq 0.1$ MM in fractions of 1 , forming a zone of increased turbidity (calculation by granulometric composition of particles within recoverable soils); $k$ is the coefficient of soil transition during the operation of technical equipment in suspension, in fractions of $1 ; Q-$ productivity of technical equipment on the ground, $\mathrm{m}^{3} / \mathrm{h}$ (determined by the technological parameters of dredging); $\gamma$ is the design volumetric weight of the soil in the state of natural addition, $\mathrm{t} / \mathrm{m}^{3} ; \gamma_{W}$ is the volumetric weight of water, $\mathrm{t} / \mathrm{m}^{3} ; \gamma_{S}$ is the specific gravity of soil particles, $\mathrm{t} / \mathrm{m}^{3}$;

$$
\tau<\frac{\Delta s}{\sqrt{g H_{\max }}}
$$

- stability criterion for Courant-Friedrichs-Levy spacing calculations (CFL criterion); $H_{\max }$ is the maximum depth, $\mathrm{m} ; \Delta s$ - step of grid in spatial coordinates; $\mathrm{g}$ is constant, $9.81 \mathrm{~m} / \mathrm{sec}^{2}$;

$$
\left(A_{\eta}\right)_{n}=\alpha \cdot\left(h_{x} \cdot h_{y}\right) \cdot \sqrt{2\left(\frac{\partial U}{\partial x}\right)^{2}+\left(\frac{\partial U}{\partial y}+\frac{\partial V}{\partial x}\right)^{2}+2\left(\frac{\partial V}{\partial y}\right)^{2}}
$$

- equation for estimating the coefficient of horizontal turbulent exchange; $h_{x}, h_{y}$ - grid steps along the spatial coordinates $x$ and $y$, respectively; $\alpha$ is a coefficient equal to 0.1 ; $\partial U / \partial x, \partial U / \partial y, \partial V / \partial x, \partial V / \partial y$ are derivatives, and the central-difference approximation was used to calculate them;

$$
\tau_{\text {bottom }}=\tau_{\text {bottom }}^{\text {curr }}+\tau_{\text {bottom }}^{\text {wave }}
$$

- equation for calculating the tangential stress at the bottom of the water body - the sum of the tangential stresses due to the effects of currents and waves on the bottom of the water body;

$$
\tau_{\text {bottom }}^{\text {curr }}=\rho_{w} \cdot C_{D} \cdot\left(U^{\text {curr }}\right)^{2}
$$

- equation for calculating the tangential stress at the bottom of a reservoir by the influence of currents; $\rho_{W}$ is the density of sea water; $C_{D}$ is the drag coefficient; $U^{\text {curr }}$ - vertical average flow velocity of water;

$$
C_{D}=0,16 \cdot\left(1+\ln \left(\frac{Z_{0}}{Z_{w}}\right)\right)^{-2}
$$

- equation for calculating the coefficient $C_{D} ; Z_{0}$ is the average scale of the height of the 
bottom roughness; $Z_{W}$ - water depth in the place for which the calculations are made (the average from the sum of the average depths for different stages of work);

$$
h_{\text {sed }}=\frac{M_{\text {sed }}}{\gamma \cdot S_{\text {sed }}}
$$

- equation for calculating the thickness, $h_{\text {sed }}$, of layer of the precipitated sediment, $\mathrm{m}$; $M_{\text {sed }}$ - sediment mass settling to the bottom, $t ; \gamma$ is the volumetric weight of the soil in a state of natural composition, $\mathrm{t} / \mathrm{m}^{3} ; S_{\text {sed }}$ - area on which precipitation falls, $\mathrm{m}^{2}$;

$$
V_{\text {sed }}=S_{\text {sed }} \times h_{\text {sed }}
$$

- total volume of precipitated sediments, $\mathrm{m}^{3}$;

$$
\gamma=M_{\text {sed }} / V_{\text {sed }}
$$

- equation for calculating the volumetric weight of soil in the natural state $\gamma, \mathrm{t} / \mathrm{m}^{3}$

$$
G=P \cdot k_{1} \cdot V \cdot \gamma_{S} \cdot \frac{\gamma-\gamma_{W}}{\gamma_{S}-\gamma_{W}}
$$

- equation for calculating the mass of soil turning into a suspended state when dumping soil into an underwater dump; $P$ is the weighted total content of suspended particles $(0.1 \mathrm{~mm}$ in size, in fractions of 1$)$ in the soil, forming the AWT zone (determined by the particle size distribution of suspended matter); $k_{1}$ is the coefficient of soil transition during the operation of technical means in suspension when dumping soil into an underwater dump, in fractions of 1; $V$ - loading norm of the vessel's hold in terms of volume in the state of natural composition, $\mathrm{m}^{3} ; \gamma, \gamma_{W}, \gamma_{S}$ - see explanations in equation (3).

\section{References}

Chao X., Jia Y., Shields Jr. F.D., Wang S.S.Y., and Cooper C.M. Three-dimensional modeling of cohesive sediment transport and wind wave impact in a shallow oxbow lake. Adv. in Water Res., 2008, Vol. 31, pp. 1004-1014.

Guidelines for calculating the distribution of turbidity zones during dredging and dumping in the water areas of Navy. Moscow: Defense Ministry of the Russian Federation, 2003, 80 p. (In Russian).

Hamilton D.P. and Mitchell S.F. An empirical model for sediment resuspension in shallow lakes. Hydrobiologia, 1996, Vol. 317, pp. 209-220.

Hydrometeorological regime of the Vistula lagoon. Eds. N.N. Lazarenko, A. Mayevsky, Leningrad: Hydrometeoizdat, 1971, 279 p. (In Russian).

Lou J., Schwab D.J., Beletsky D., and Hawley N. A model of sediment resuspension and transport dynamics in southern Lake Michigan. J. Geophys. Res., 2000, Vol. 105, pp. 6591-6610.

Mehta A.J. and Partheniades E. An investigation of the depositional properties of flocculated fine sediment. J. Hydraul. Res., 1975, Vol. 13, pp. 361-381.

Oil and the environment of the Kaliningrad region. T. II: The sea / Eds. V.V. Sivkov, Yu.S. Kajoian, O.E. Pichuzhkina, V.N. Feldman. Kaliningrad: Terra Baltika, 2012, 576 p. (In Russian).

Podgorny K.A. Mathematical modeling of freshwater ecosystems of unstratified water bodies (algorithms and numerical methods). Rybinsk: Publishing house of OAO "Rybinsk House of Printing", 2003, 328 p. 
Podgorny K.A. and Leonov A.V. Simulation of the processes of distribution of suspended matter in marine coastal areas. 1. Description of the SM-model. Journal of Oceanological Research. 2017a, No. 45, pp. 109-141.

Podgorny K.A. and Leonov A.V. Simulation of the processes of distribution of suspended matter in marine coastal areas. 2. Testing and practical application of the SM-model. Journal of Oceanological Research, 2017b, No. 45, pp. 142-162.

Stanev E.V., Dobrynin M., Pleskachevsky A., et al. Bed shear stress in the southern North Sea as an important driver for suspended sediment dynamics. Ocean Dynamics, 2009, Vol. 59, pp. 183-194.

Ziegler C.K. and Nisbet B.S. Long-term simulation of fine-grained sediment transport in large reservoir. J. Hydraul. Eng., 1995, Vol. 121, pp. 773-781.

\title{
РАСЧЕТ ЗНАЧЕНИЙ ПАРАМЕТРОВ ДЛЯ ХАРАКТЕРИСТИКИ ПОСЛЕДСТВИЙ РАБОТ ПО ДНОУГЛУБЛЕНИЮ И ДАМПИНГУ ДОННЫХ ОСАДКОВ: ОЦЕНКА С ПОМОЩЬЮ ВВ-МОДЕЛИ
}

\author{
Подгорный К.А. ${ }^{1}$, Леонов А.В. ${ }^{2}$ \\ ${ }^{1}$ Атлантический НИИ рыбного хозяйства и океанографии \\ Россия, 236000, г. Калининград, ул. Дм. Донского, 5, \\ e-mail:kapborok@mail.ru \\ ${ }^{2}$ Институт океанологии им. П.П. Шириова, РАН \\ Россия, 117997, Москва, Нахимовский проспект, 36, \\ e-mail:leonov@ocean.ru
}

Статья поступила в редакцию 06.07.2020, одобрена к печати 28.08.2020

\begin{abstract}
Разработанная ВВ-модель использована для оценки последствий планируемых работ по дноуглублению и дампингу грунта по проекту реконструкции и модернизации территории порта г. Пионерский (Калининградская область). Комплекс работ включает 11 этапов, в ходе которых при дноуглублении со дна извлекаются донные осадки разного типа, часть этих осадков переносится за пределы акватории порта и сбрасывается в морской подводный отвал, а часть используется для гидротехнических строительных работ в порту. При дноуглублении и дампинге грунта образуются зоны дополнительной мутности воды (с концентрацией взвешенного вещества >50 мг/л), его осаждение вызывает формирование слоя осадков на дне. В процессе математического моделирования по каждому этапу работ вычисляются по технологическим данным о проекте течения в акватории порта, количества извлекаемых со дна грунтов разного типа, их перераспределения по морской акватории, концентрации взвешенных веществ в морской воде и показатели (площади и объемы) формирующихся зон дополнительной мутности воды вследствие строительных работ. Расчетные данные могут быть использованы для составления ОВОС по данному проекту.
\end{abstract}

Ключевые слова: природные факторы, образование взвешенного вещества, зоны повышенной мутности воды, слой дополнительных осадков

Благодарность: Финансовая поддержка исследований в АтлантНИРО (Калининград) была оказана при реализации проекта по строительству Международного морского терминала (MМТ) в п. Пионерский Калининградской области и в Инсти- 
туте океанологии им. П.П. Ширшова РАН (Москва) - в рамках темы № 0128-20190011 «Взаимодействие биогеосфер Мирового океана».

\section{Литература}

Гидрометеорологический режим лагуны р. Вистула / Ред. Н.Н. Лазаренко, А. Маевский. Л.: Гидрометеоиздат, 1971. 279 с.

Методические указания по расчету распространения зон мутности при дноуглублении и дампинге на акваториях ВМФ. М.: МО РФ, 2003. 80 с.

Нефть и окружающая среда Калининградской области. Т. II: Море / под ред. В.В. Сивкова, Ю.С. Кейджана, О.Е. Пичужкиной, В.Н. Фельдмана. Калининград: Терра Балтика, 2012. $576 \mathrm{c}$.

Подгорный K.A. Математическое моделирование пресноводных экосистем нестратифицированных водоемов (алгоритмы и численные методы). Рыбинск: Издво ОАО Рыбинский Дом печати, 2003. 328 с.

Chao X., Jia Y., Shields Jr. F.D., Wang S.S.Y., Cooper C.M. Three-dimensional modeling of cohesive sediment transport and wind wave impact in a shallow oxbow lake // Adv. in Water Res. 2008. Vol. 31. P. 1004-1014.

Hamilton D.P., Mitchell S.F. An empirical model for sediment resuspension in shallow lakes // Hydrobiologia. 1996. Vol. 317. P. 209-220.

Lou J., Schwab D.J., Beletsky D., Hawley N. A model of sediment resuspension and transport dynamics in southern Lake Michigan // J. Geophys. Res. 2000. Vol. 105. P. 6591-6610.

Mehta A.J., Partheniades E. An investigation of the depositional properties of flocculated fine sediment // J. Hydraul. Res. 1975. Vol. 13. P. 361-381.

Podgorny K.A., Leonov A.V. Simulation of the processes of distribution of suspended matter in marine coastal areas. 1. Description of the SM-model // Journal of Oceanological Research. 2017 a. No. 45. P. 109-141.

Podgorny K.A., Leonov A.V. Simulation of the processes of distribution of suspended matter in marine coastal areas. 2. Testing and practical application of the SM-model // Journal of Oceanological Research. 2017 b. No. 45. P. 142-162.

Stanev E.V., Dobrynin M., Pleskachevsky A., et al. Bed shear stress in the southern North Sea as an important driver for suspended sediment dynamics // Ocean Dynamics. 2009. Vol. 59. P. $183-194$.

Ziegler C.K., Nisbet B.S. Long-term simulation of fine-grained sediment transport in large reservoir // J. Hydraul. Eng. 1995. Vol. 121. P. 773-781. 